1
1

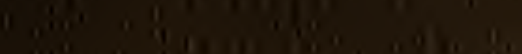

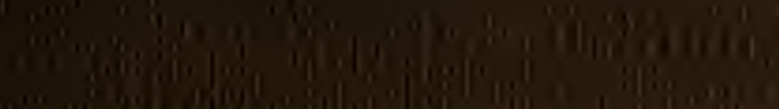

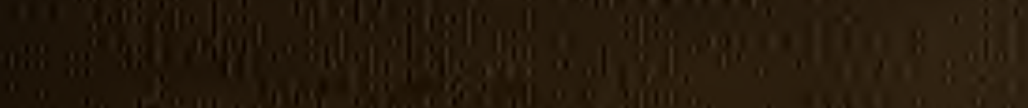

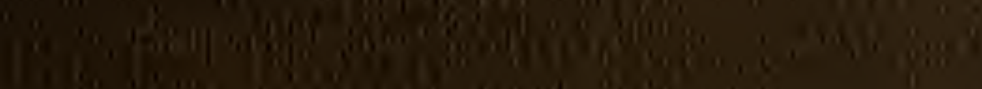

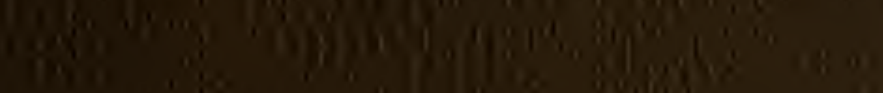
-

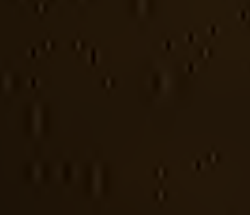

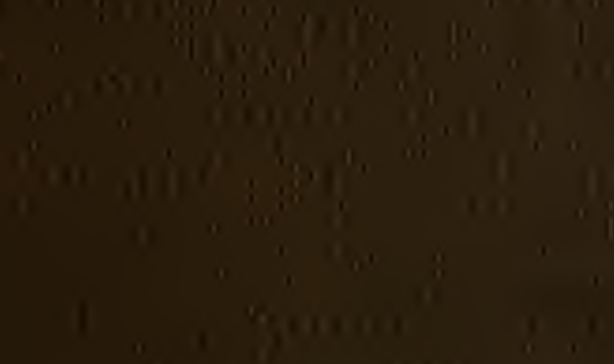

14
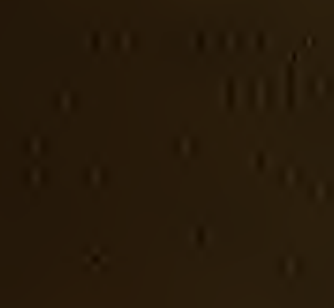

111 


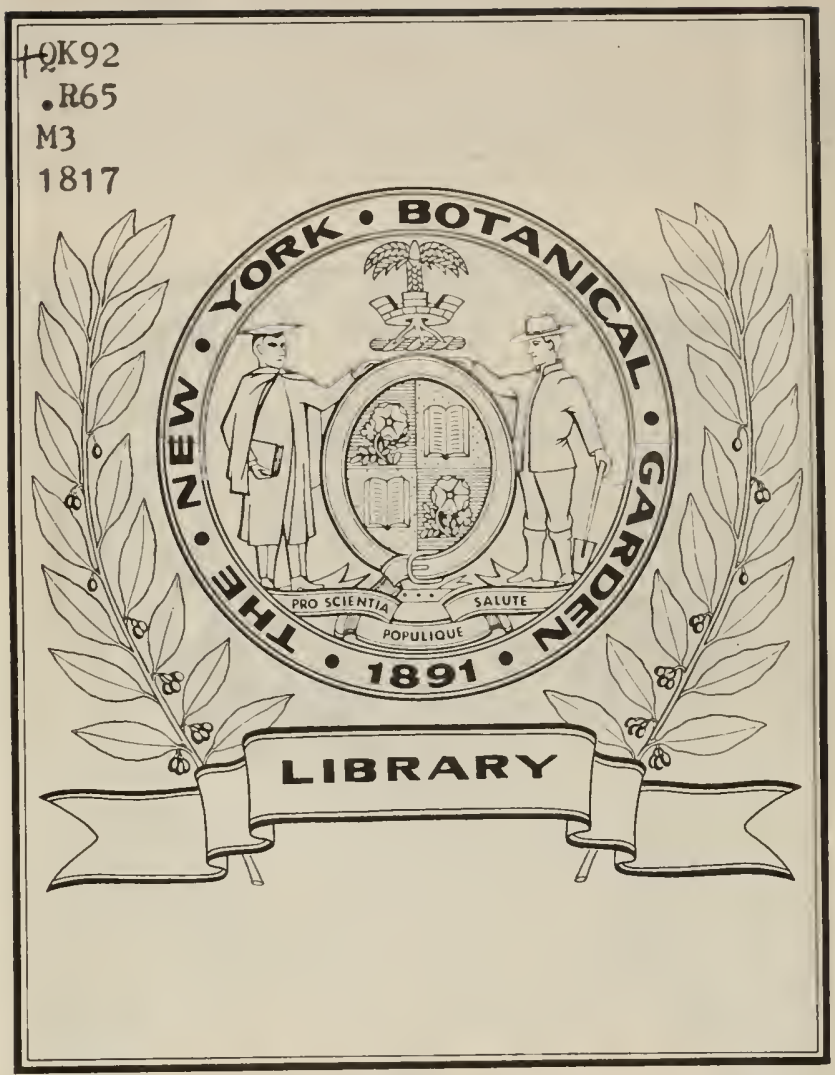

[100n) 


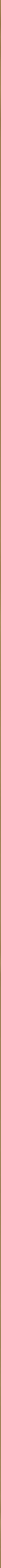







\title{
THIRTY-EIGHT PLATES,
}

\author{
WITH
}

\section{EXPLANATIONS;}

\author{
INTENDED TO ILLUSTRATE
}

\section{LINN EUS`s SYSTEM of VEGETABLES,}

\author{
AND PAKTICULARLY ADAPTED TO THE
}

LETTERS ON THE ELEMENTS OF BOTANY.

By THOMAS MARTYN, B.D.F.R.\& L.S.S.

REGIUS PROFESSOR OF BOTANY

IN THE UNIVERSITY OF CAMBRIDGE.

\section{A NEW EDITION.}

\section{LON DON :}

PRINTED FOR LONGMAN, HURST, REES, ORME, AND BROWNE; BALDWIN, CRADOCK, AND JOY; J. CUTHELL; J. MAWMAN; LACKINGTON AND CO.; J. BLACK AND SON; AND J.BOOTH. 
+xy?

. R 65

$M 3$

1817

Printed by Nichols, Son, and Bentley, Red Lion Passage, Fleet Street, London. 


\section{ADVERTISEMENT.}

Some persons, who have honoured the Letters on the Elements of Botany with their approbation, having signified a wish that the subject might be still farther illustrated by figures, Mr. NoDDER, an ingenious artist, has been employed for this purpose, and has both drawn and engraved thirtyeight plates. By these, and the explanations which are given on the opposite page, the Author hopes that he may have met the ideas of his friends. 


\section{( iv )}

These Plates, with their explanations, may be considered as an entire work; but it is presumed that they will be much more satisfactory when studied jointly with the Letters.

Six plates are given to illustrate Rousseau's six letters upon the most remarkable Natural Classes. The rest are intended to explain the Classes of Linnæus's System in their order, except the thirty-fourth, which exhibits figures of the most remarkable Nectaries. No general plate, explanatory of the classical characters, is given; both because it has already been elegantly done by Mr. Curtis, and also may easily be collected from the particular plates of this work. 


\section{( v )}

Thus the character of the Class

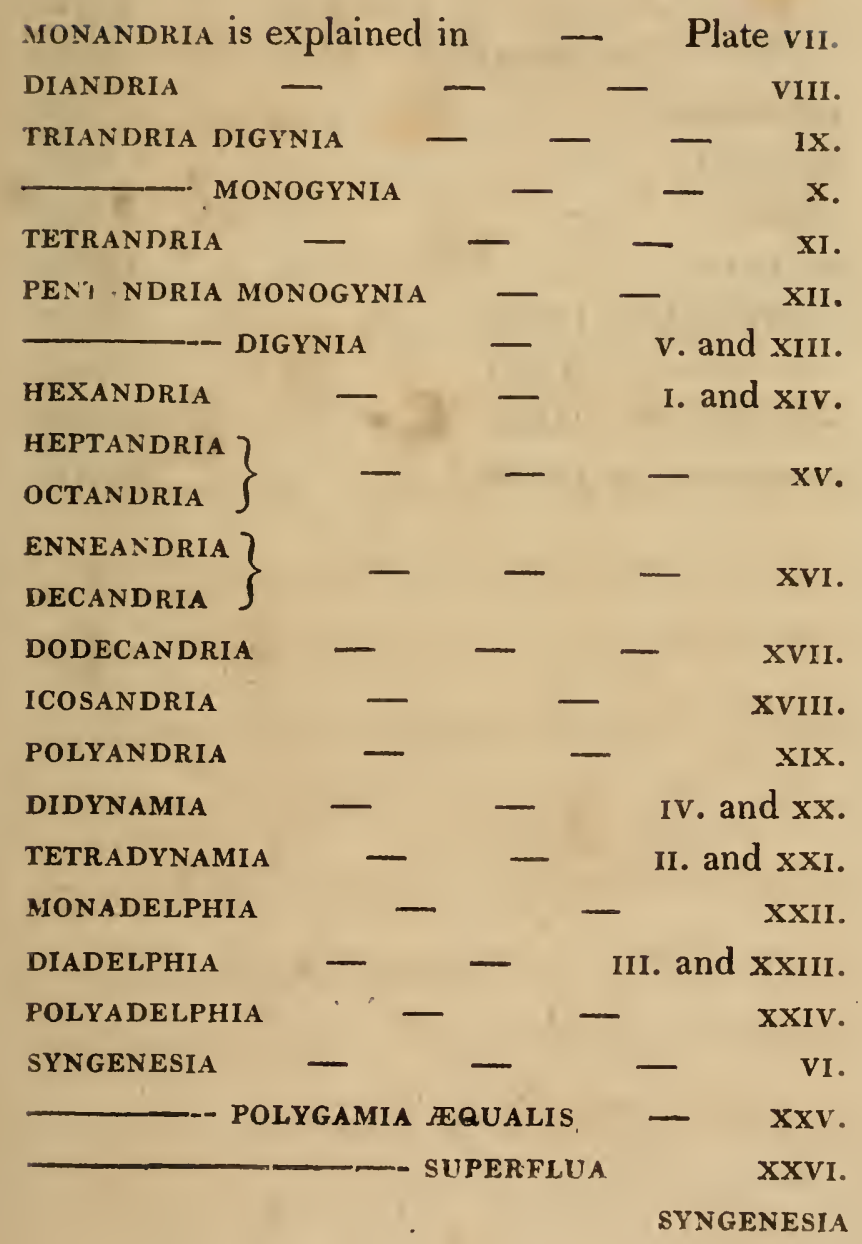




\section{( vi )}

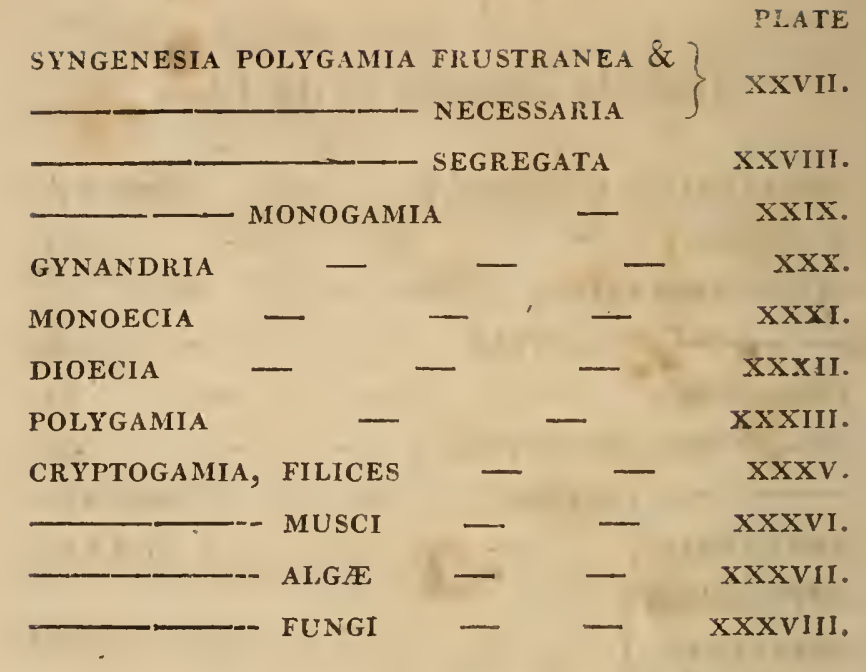




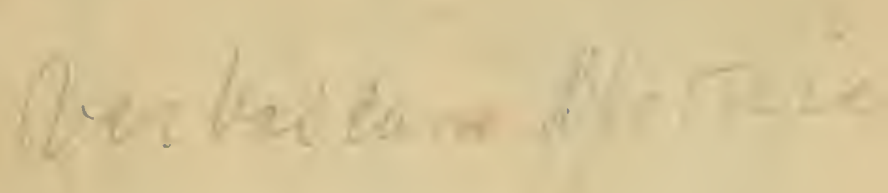




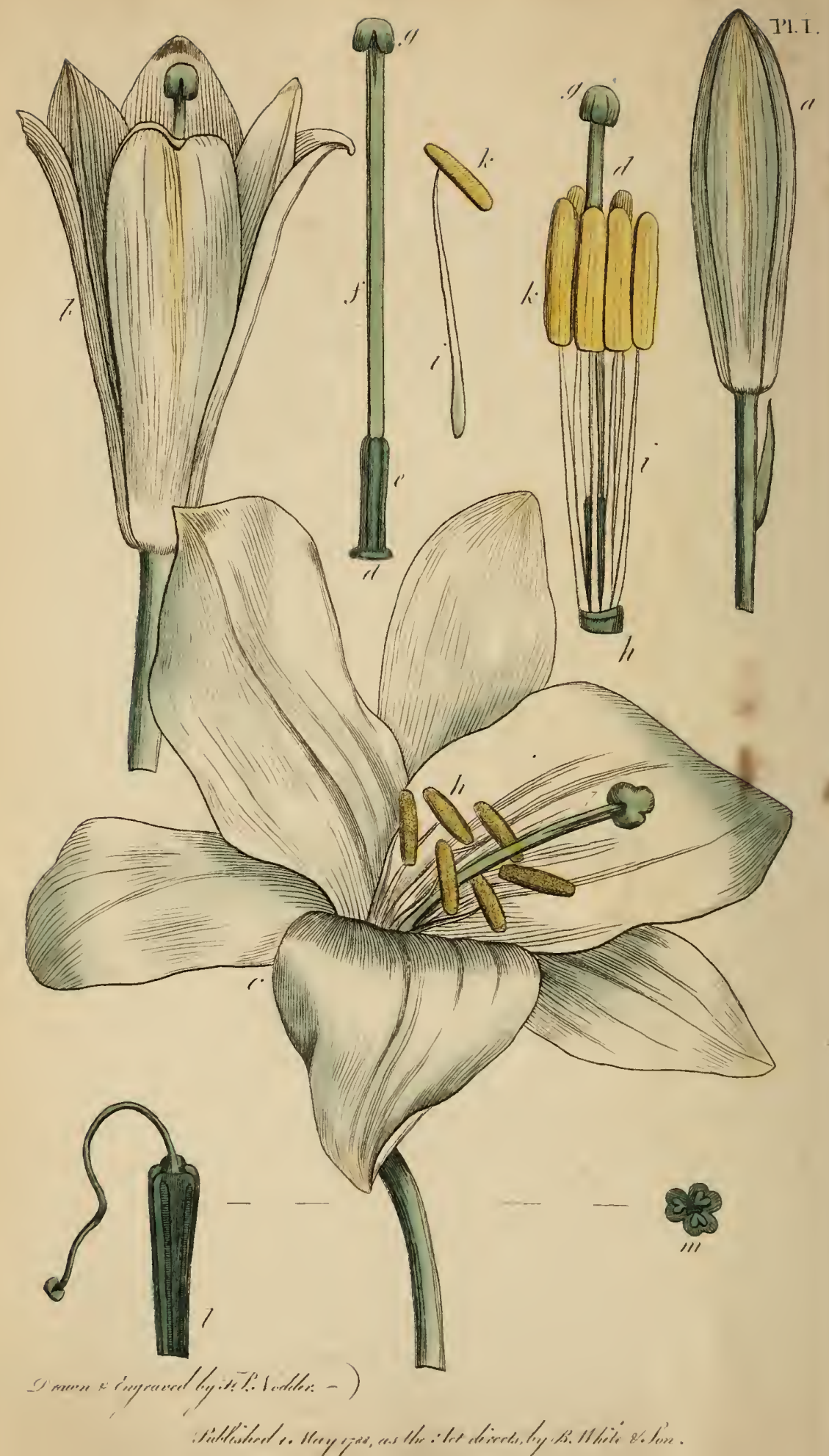


$(1)$

PLATE I. LETTER I.

'LILIACEOUS FLOWERS.

Lilium candidum. White Lily.

a The flower in bud.

$b$ The corolla expanding.

c The corolla quite open.

$d$ The pistil or pointal. $e$ The germ.

$f$ The style. $g$ The stigma.

$b$ The six stamens. $i$ The filaments.

$k$ The anthers.

l The germ advanced into a pericarp, which here is a capsule.

$m$ A transverse section of the pericarp, to show the three cells and seeds. 
$-$

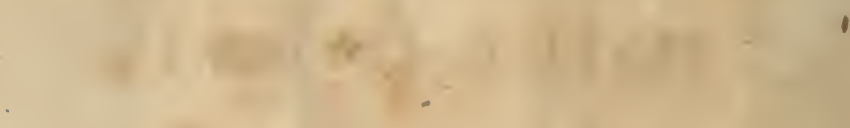

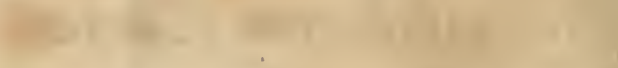

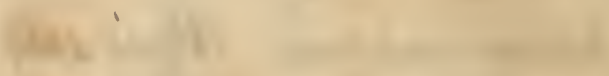
$\sqrt{1+20}+$

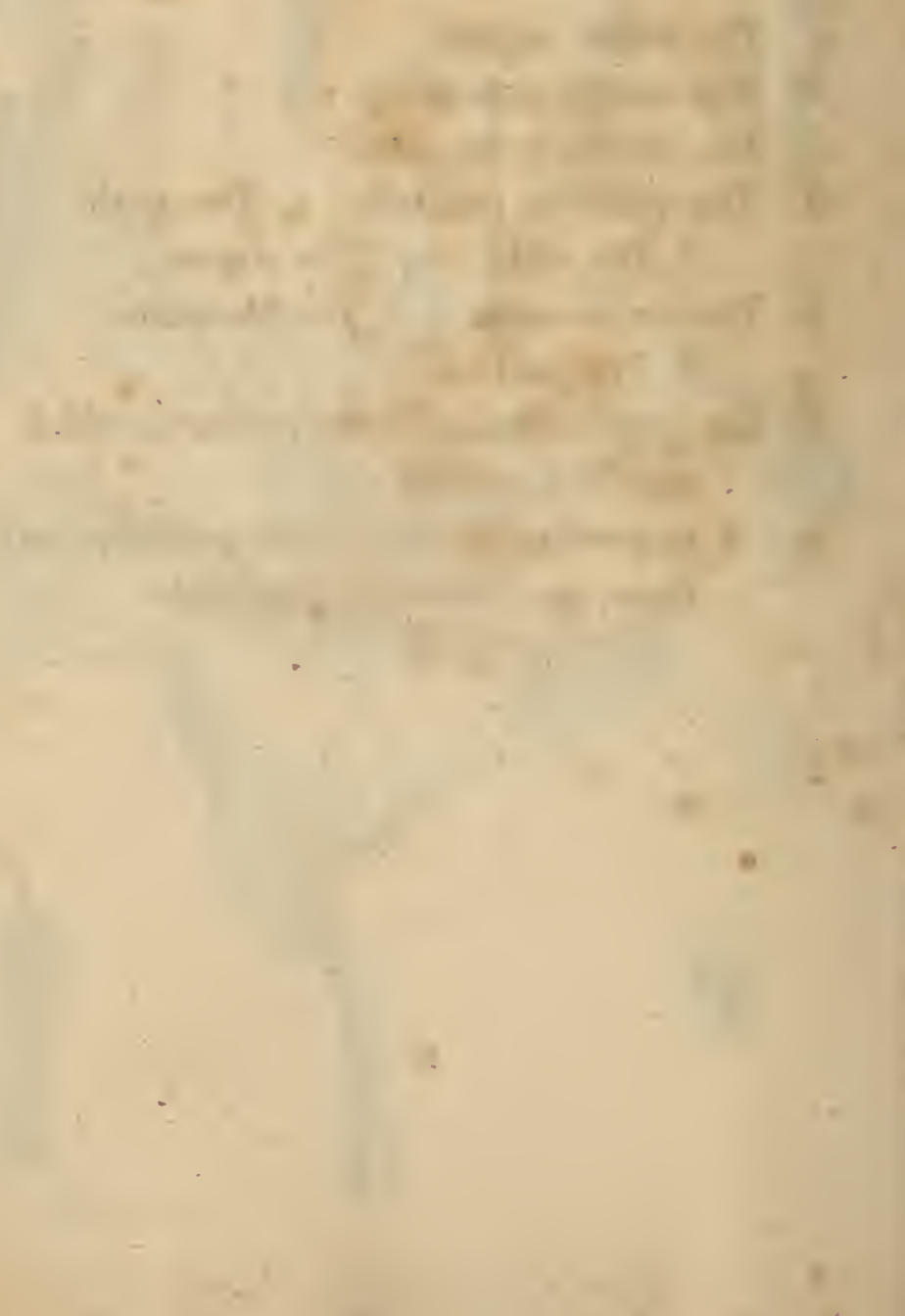



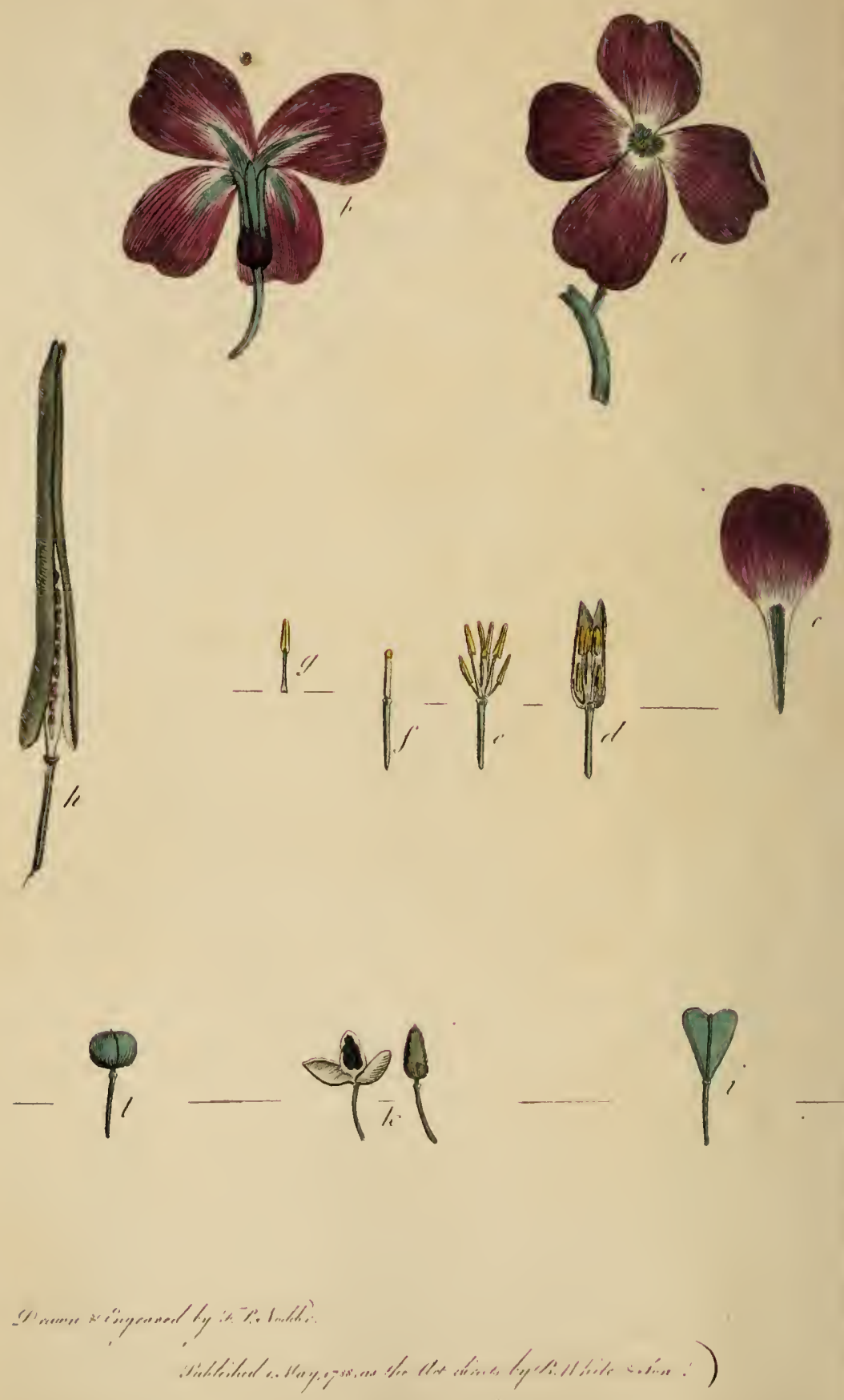


\section{$(3)$}

\section{PLATE II. LETTER II.}

\section{CRUCIFORM FLOWERS.}

Cheiranthus incanus. Stock-Gilliflower.

a A flower of the stock, showing the four petals and the cruciform shape of the corolla.

b. A back view of it, exhibiting the calyx, consisting of four leaflets, and bulging out at the bottom.

c A single petal separated, to show the lower narrow part, called unguis, or the tail; and the upper spreading part, named lamina, or the border, emarginate or notched at the end.

d A section of the calyx, with the single pistil and six stamens in their proper situation.

e The six stamens, two of which are sensi-

bly shorter than the other four.

$f$ Thie pistil separated from the other parts.

$g$ A single stamen.

h. The fruit, seed-vessel, or pericarp, called a silique, opening from the bottom B 2 


\section{( 4 )}

upwards, and showing the two valves, with the seeds ranged along the dissepiment, or partition, of the two cells, and the permanent stigma at the top.

$i k l$ Figures of silicles, or small short pods or pouches.

$i$ The flat triangular, or heart-shaped silicle of the shepherd's purse.

$k$ The oblong silicle of scurvy-grass, both shut and open.

$l$ The almost spherical silicle of candy-tuft. See Letter XXIII. and Plate XXI.

$e$ Explains the classical character of the class Tetradynamia, and

$h i k l$ Explain the characters of the two orders, Siliquosa and Siliculosa, into which it is divided. 
Plate III.

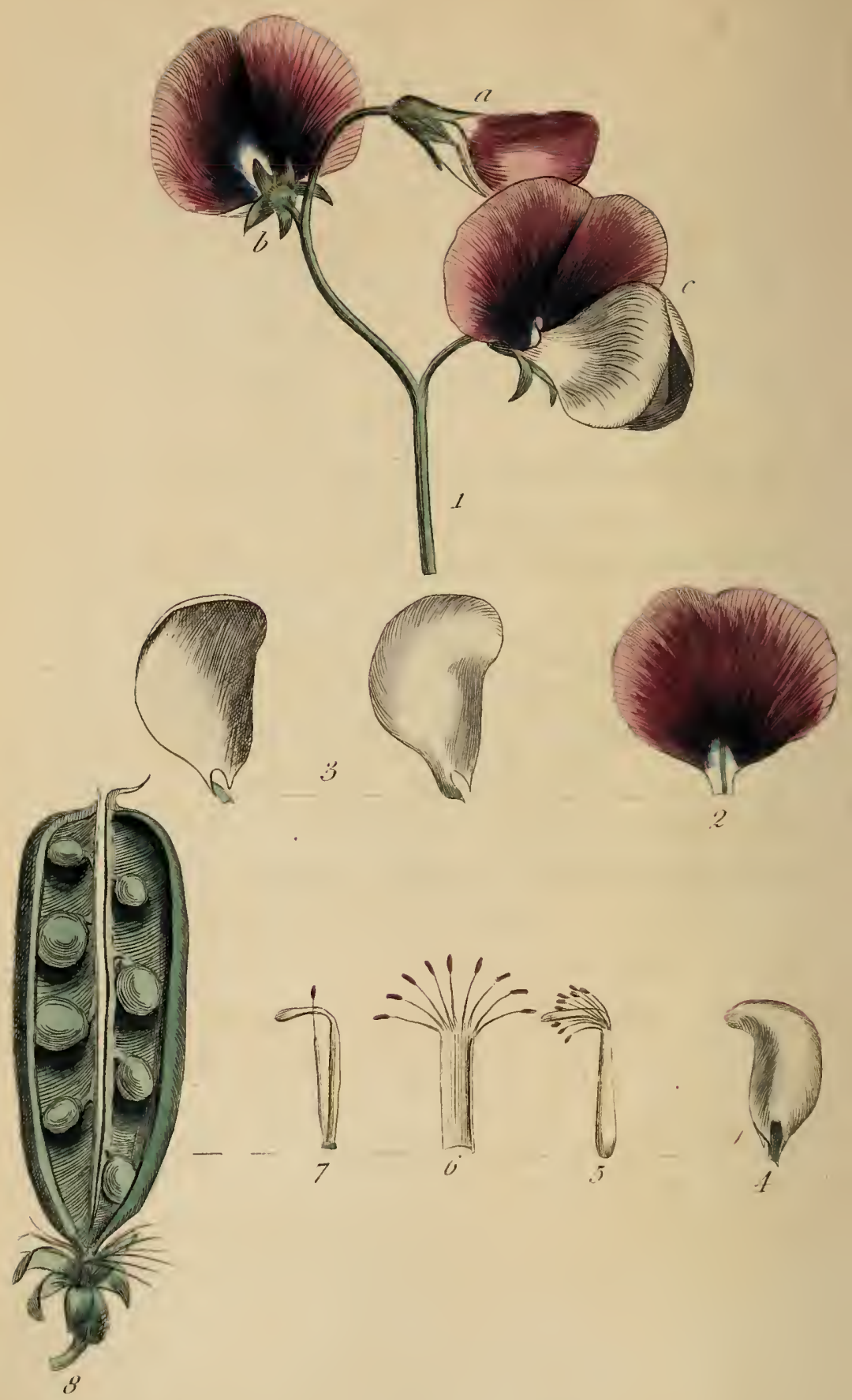




\section{( 5 )}

\section{PLATE III. L ETTER III.}

PAPILIONACEOUS FLOWERS.

Pisum sativum. Garden $P$ ea.

Fig. 1. The peduncle or flower-stem of the pea, showing the papilionaceous corolla in three different situations.

a A young flower not fully expanded.

$b$ An expanded flower, showing the back; the standard, or banner, fully displayed, and the calyx cleft into five parts.

c A side view of an expanded flower, showing the banner, wings, and keel in their natural situation.

Fig. 2. The banner (vexillum), obcordate or inversely heart-shaped, and emarginate.

3. The two wings (ala).

4. The keel (carina).

5. The pistil and stamens in their na. tural situation. 


$$
\text { (6.) }
$$

Fig 6. The lower broad stamen, which involves the germ, terminating in nine filaments, with an anther on each.

7. The upper narrow filament, accompanied with the pistil.

8. The pericarp, which is a legume, or pod, open to show the two valves and the seeds fastened alternately to the sutures of the valves at the back of the legume. The permanent calyx is also here exhibited.

Obs. The character of the class Diadelphia, and of the order Decandria, as also of the natural class of Leguminous plants, is here explained. 


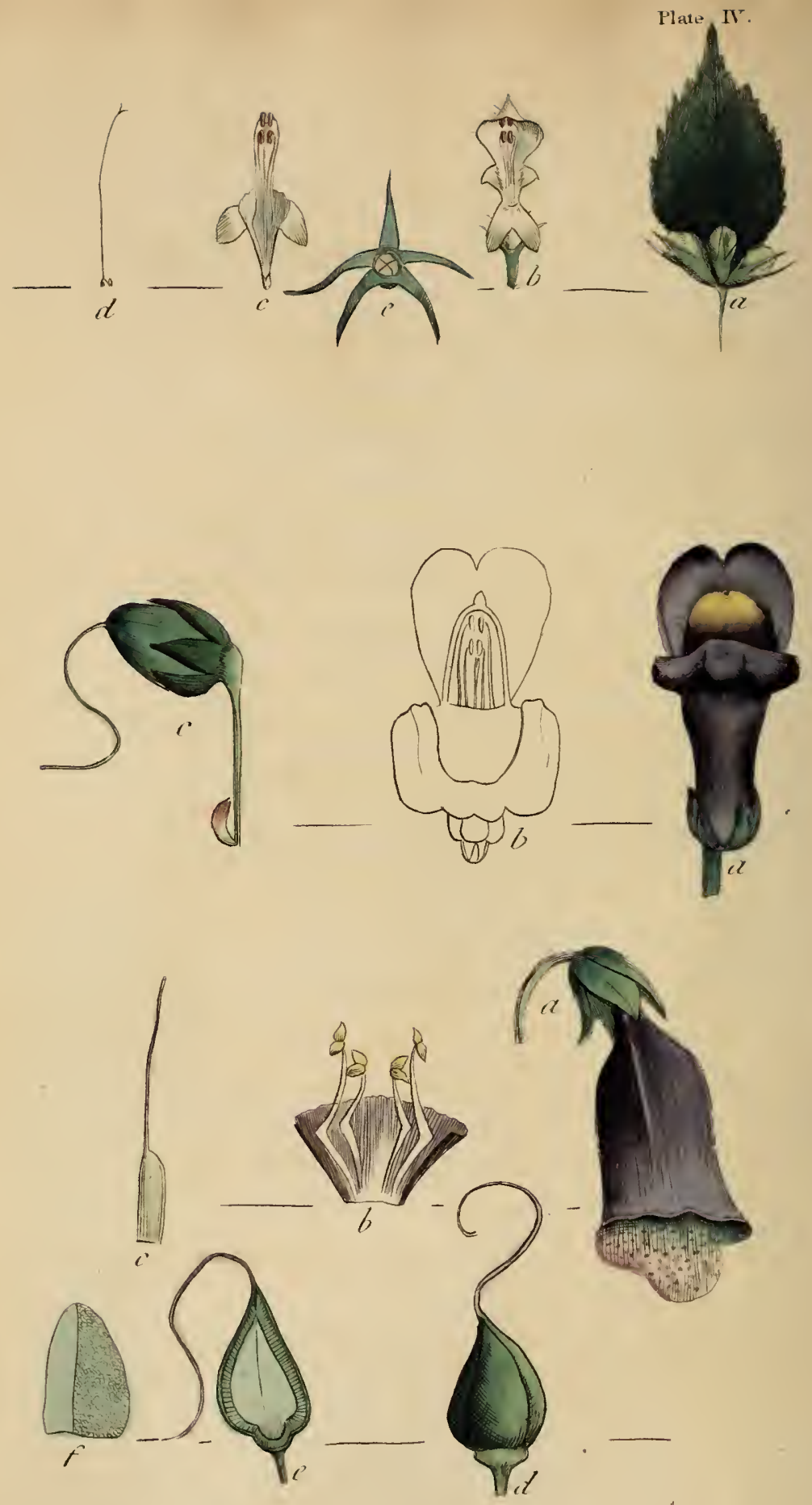


\section{$(7)$}

\section{PLATE IV. LETTER IV.}

\section{RINGENT FLOWERS.}

Fig. 1. Lamium album. White Dead Nettle.

a Part of a whorl of flowers, showing how they grow in the bosom of a leaf.

$b$ A single flower, showing the structure of a labiate or ringent corolla, and of that of the Lamium in particular.

c The corolla cut away, in order to show more distinctly the situation of the stamens, and the classical character.

$d$ The germs, with the style.

$e$ The calyx, with the four seeds within it.

Fig. 2. Antirrhinum majus. Snapdragon.

$a$ The closed ringent, or personate corolla, in its natural form.

$b$ The corolla opened, to show the situation of the stamens.

c The capsule, with the permanent style and calyx. 


\section{(8)}

Fig. 3. Digitalis purpurea. Purple Foxglove.

a A single flower, showing the open bellshaped corolla.

$b$ The inside, exhibiting the situation and structure of the stamens.

c The germ, with the style.

$d$ The capsule, with the style permanent.

$e$ A section of the capsule.

$f$ A capsule, deprived in part of its outer skin, to show the interior texture of the coat. 


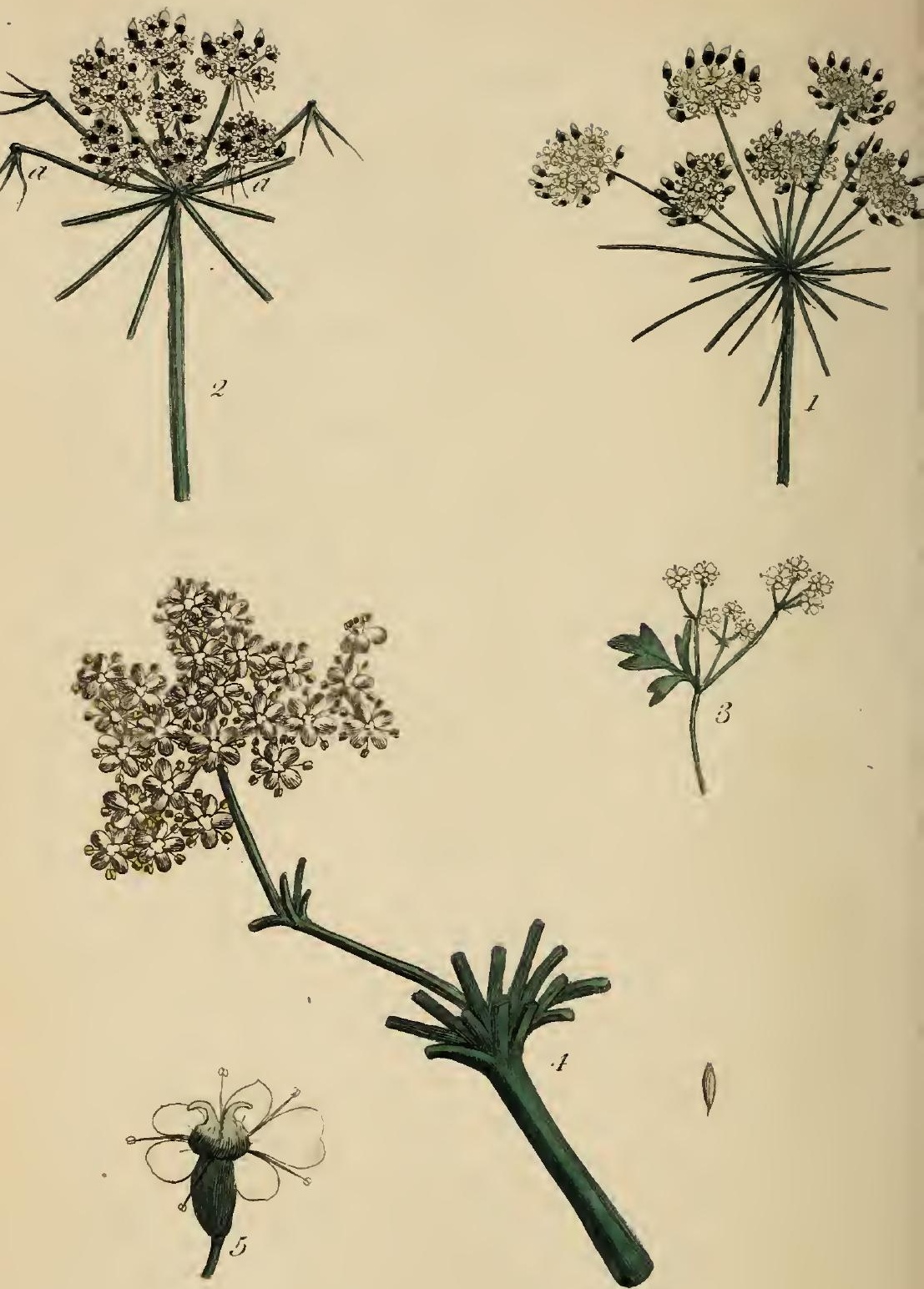


\section{( 9 )}

PLATE V. LETTER V.

UMBELLATE FLOWERS.

Fig. 1. Apium Petroselinum. Garden Parsley.

Fig. 2. Aethusa Cynapium. Fonl's Parsley.

$a$ The three long leaflets of the partial involucre, showing a principal difference between this and the true Parsley.

Fig. 3. Scandix Cerefolium. Garden Chervil.

Fig 4. Sambucus nigira. Common Elder.

To show the difference betwen that and an umbellate plant.

Fig. 5. The flower of an umbellate plant magnified, to show the particular structure.

Obs. Instances of compound umbels in Fig. 1, 2, 3, and Fig. 1, 2, of Plate XIII. A simple umbel is represented at Fig. 3, Plate XIII. 


$$
\text { (1) }
$$

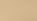

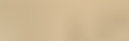

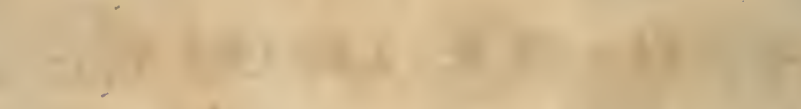

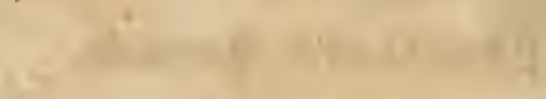

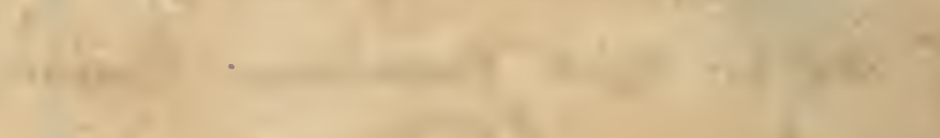

- 110

- 10.

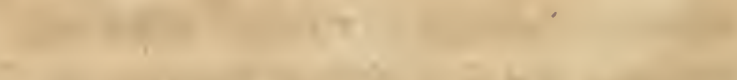

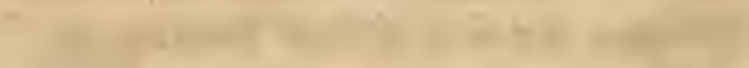

!

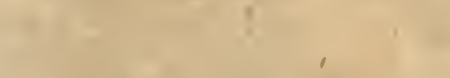

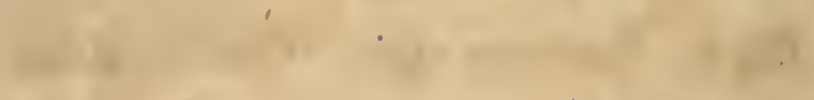

15 - i

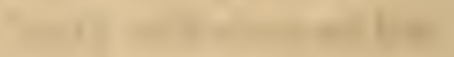

I0

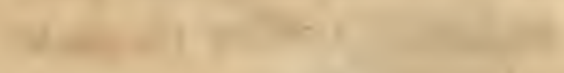

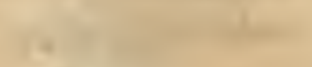

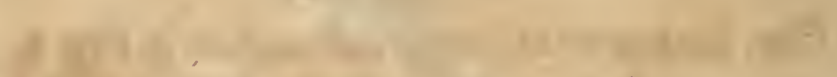

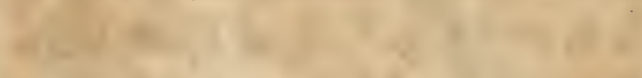

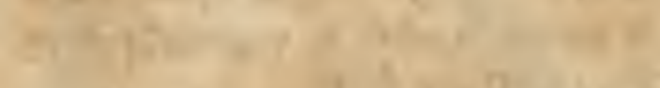

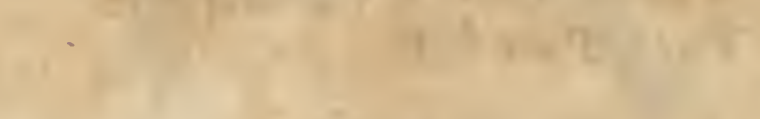

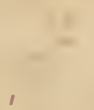




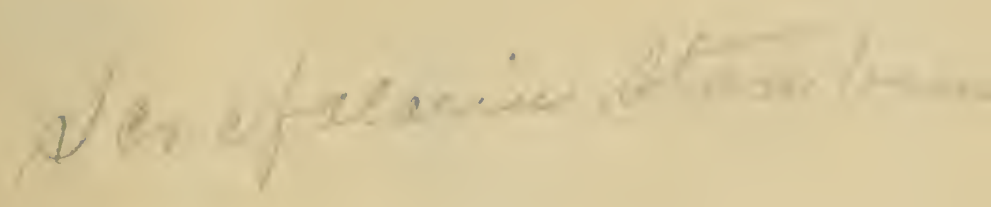




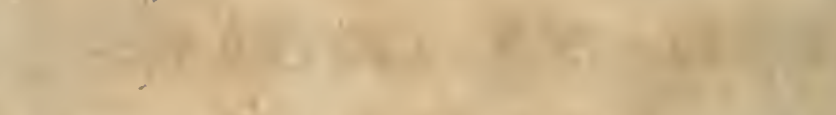

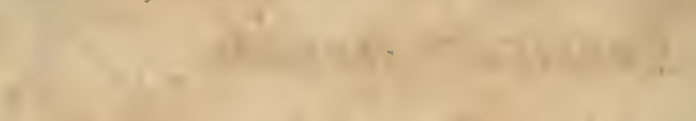

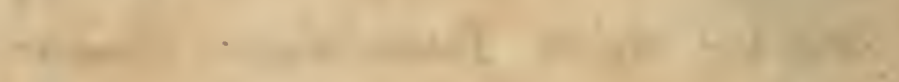

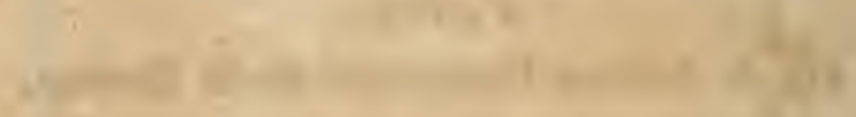
$+$ $+$

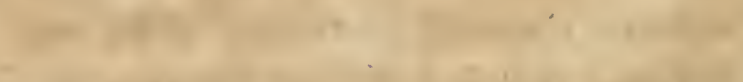

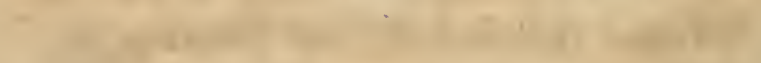

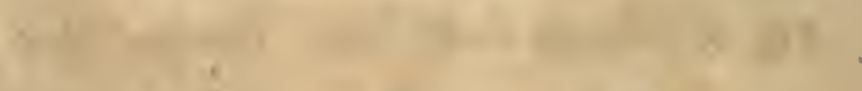
(

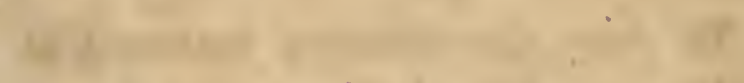

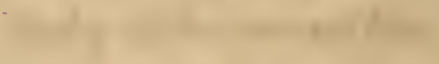

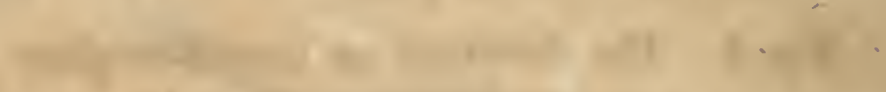

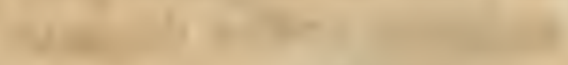

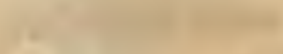

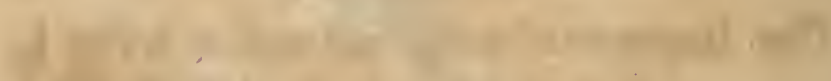

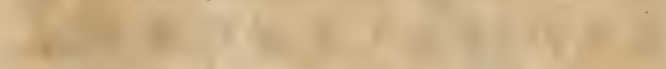

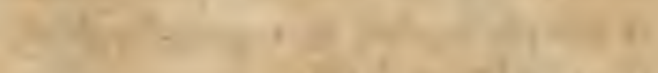

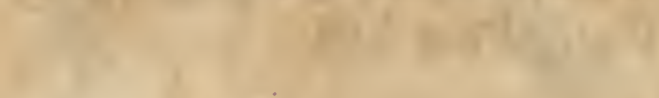

$$
\begin{aligned}
& \text { + }+ \\
& , \frac{1}{-2}
\end{aligned}
$$




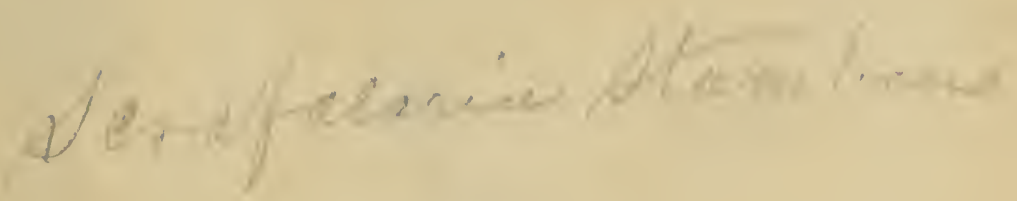



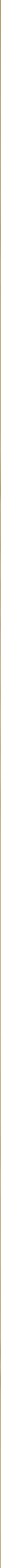

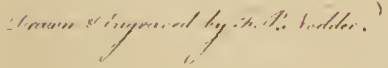




\section{( 11$)$}

PLATE VI. LETTER VI.

COMPOUND FLOWERS.

Fig. 1. Bellis perennis. Common Daisy.

a The flower, which is compound, and of the radiated kind, having semiflorets or ligulate florets in the ray, and tubular florets in the disk.

$b$ A section of the receptacle, with the florets on it.

c A serni-floret.

d The cylinder of anthers, with the style perforating it.

e A floret.

Fig. 2. Leontodon Taraxacum. Dandelion.

a The whole compound flower, consisting entirely of semi-florets, called by Linnæus ligulate florets.

$b$ A single floscule, or floret.

$c$ The head of seeds. 


\section{(12)}

Fig. 3.

Showing a flosculous flower, or a flower composed of florets only, called by Linnæus tubular florets.

a The whole compound flowers.

b A single floscule.

c The back of a compound flower, showing the calyx.

Fig. 4. Trifolium pratense. Red Clover.

To show the difference between this, which is a head or aggregate of flowers, and a genuine compound flower, such as Fig. 1, 2, 3, exhibit. 
Phiendelpricius.

concustion

dyrigin 


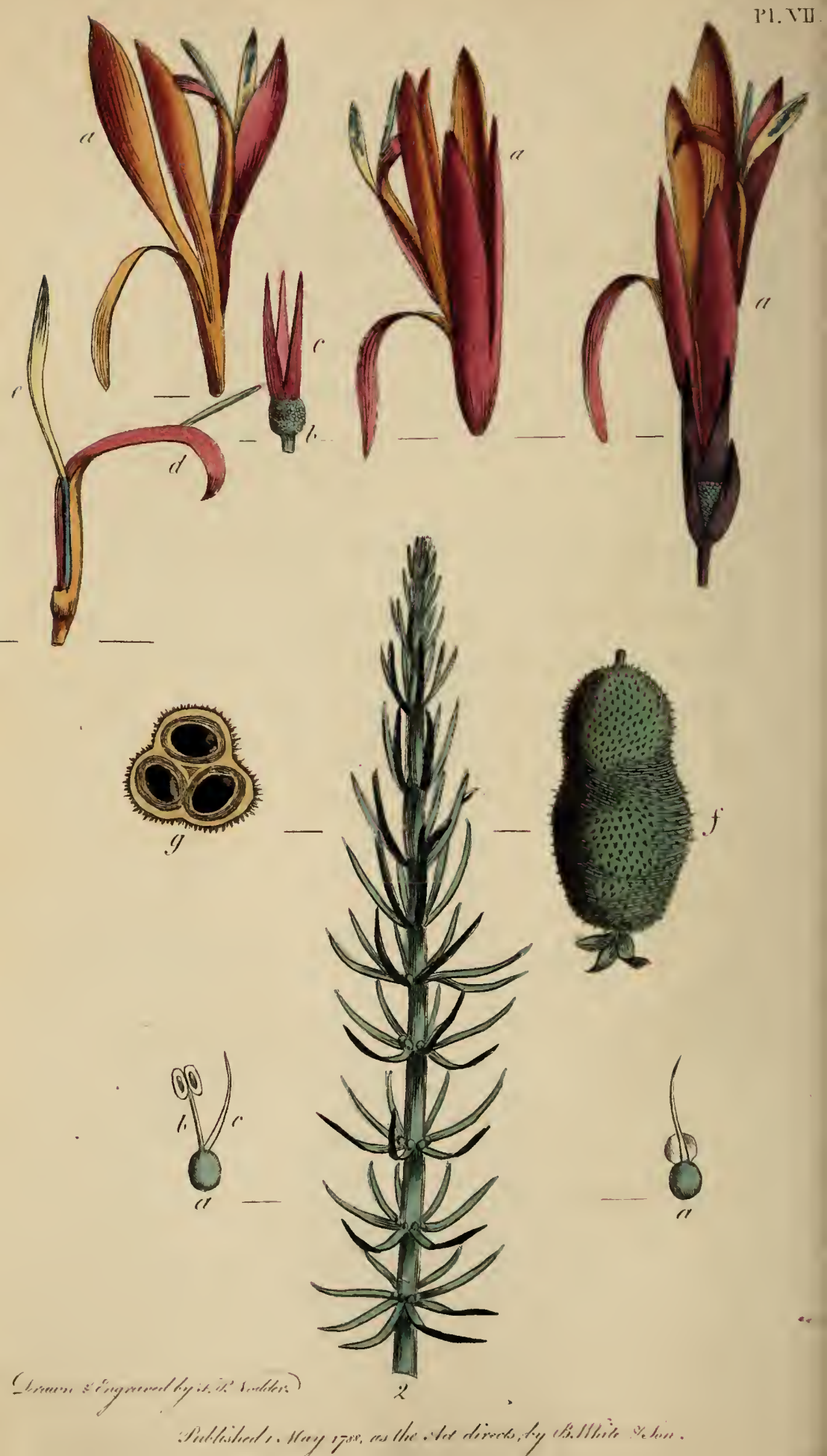




\section{(13)}

\section{PLATE VII. LETTER XI.}

MONANDRIA.

Fig. 1. Canna Indica. Indian Shot.

a a a Three different views of the flower, the corolla cut into six lanceolated parts, one of the three interior reflected.

b) The scabrous germ, with

c The triphyllous perianth, or calyx, on the top of it.

d The anther growing to one of the petals, which serves it for a filament.

$e$ The style, growing to the petaliform filament.

$f$ 'The scabrous capsule.

$g$ Cut open to show the three cells.

Fig. 2. Hippuris vulgaris. Mare's Tail'.

a a The germ.

$b$ The stamen.

c The style. 
Graluation

4.

cow 
$f x^{\prime}+\mathrm{kc}$

$$
\begin{aligned}
& 1+8 \times-1=2 \\
& x_{x=1}=\dot{x}
\end{aligned}
$$




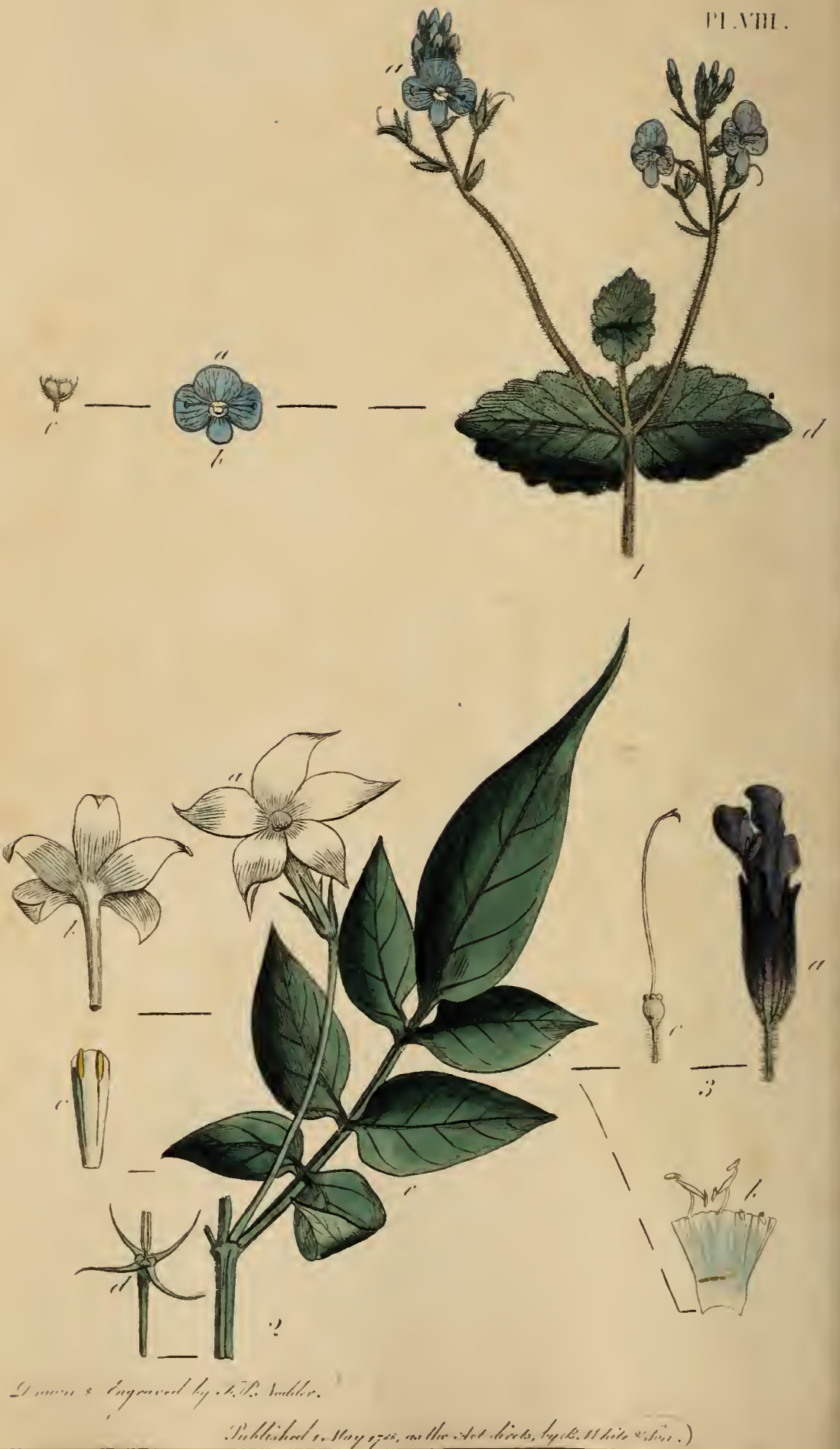




\section{( 15$)$}

\section{PLATE VIII. LETTER XII.}

\section{DIANDRIA.}

Fig. 1. Veronica Chamædrys. Wild Speedwell.

$a$ The wheel-shaped corolla, divided into four segments, the lowest (b) narrower than the rest.

c The capsule.

$d$ The oval, wrinkled leaves, indented about the edge.

Fig. 2. Jasminum officinale. White Jasmine.

a A front view of the monopetalous salvershaped corolla, divided into five segments.

$b$ A back view of the corolla.

c The tube of the corolla, with the anthers lying within it.

$d$ The calyx, with the rudiment of the fruit.

$e$ A leaf pinnated, with all the lobes distinct. 


\section{( 16$)$}

Fig. 3. Salvia officinalis. Garden Sage.

a A flower.

$b$ The two stamens, showing their singular structure.

c. The pistil separate. 



\section{( 17$)$}

\section{PLATE IX. LETTER XIII.}

TRIANDRIA DIGYNIA, GRASSES.

Fig. 1. Lolium perenne. Ray Grass.

As an instance of a spiked grass.

Fig. 2. Dactylis glomerata. Hard Grass.

$a$ The chaff or glume.

$b \quad b \quad b$ The three stamens.

$c$ The two reflected styles, with the feathered stigmas. 



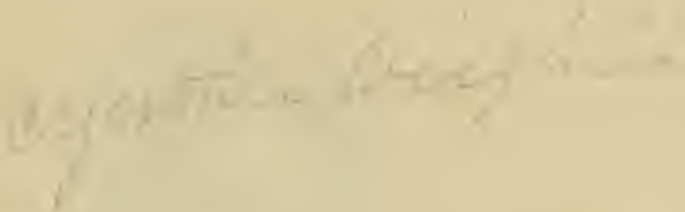


I'I. X.

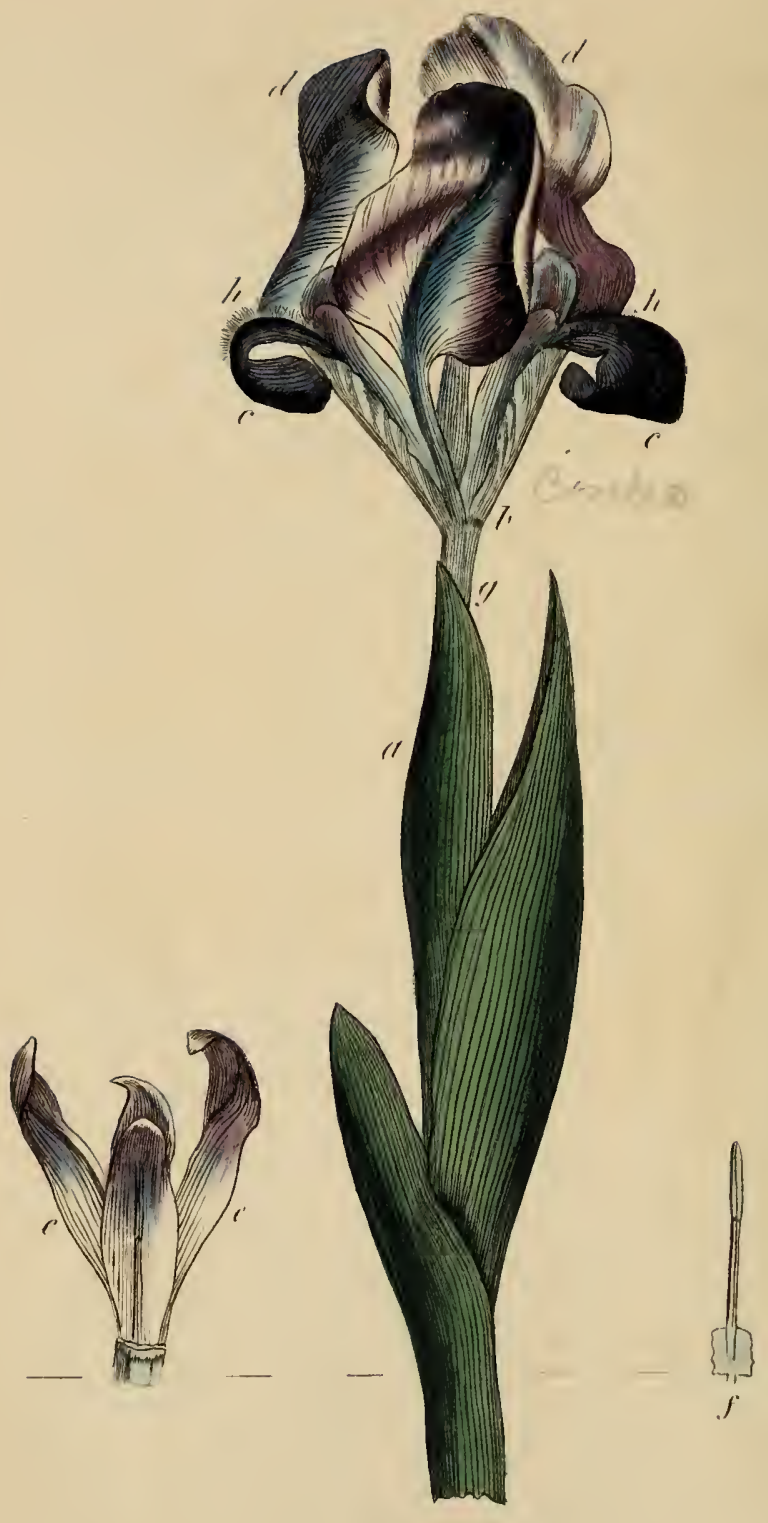

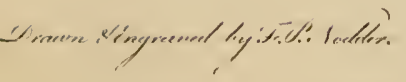

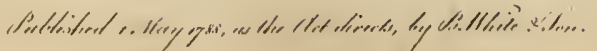




\section{( 19 )}

\section{PLATE X. LETTER XIV.}

TRIANDRIA MONOGYNIA.

Iris pumila.

a The sheath, or spathe.

$b$ The corolla, consisting of six parts, united at the base.

c $c$ The outer petals, called falls.

$d d$ The inner petals, called standards.

$e e$ The petal-form stigma, each part concealing one stamen under it.

$f$ A single stamen.

$g$ The germ, inferior, or below the corolla. $h h$ The nectary, in a villous line along the reflected petals. 

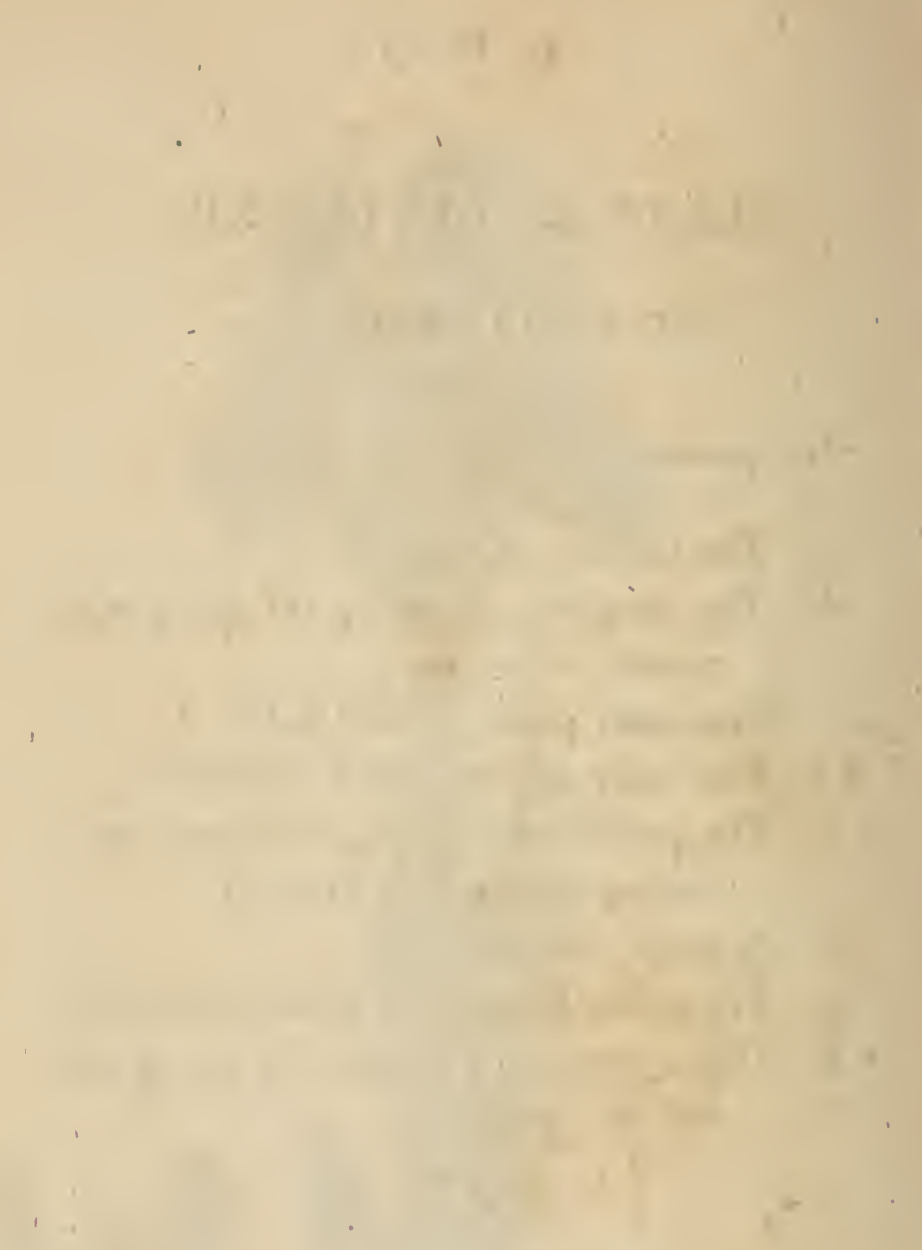

. 


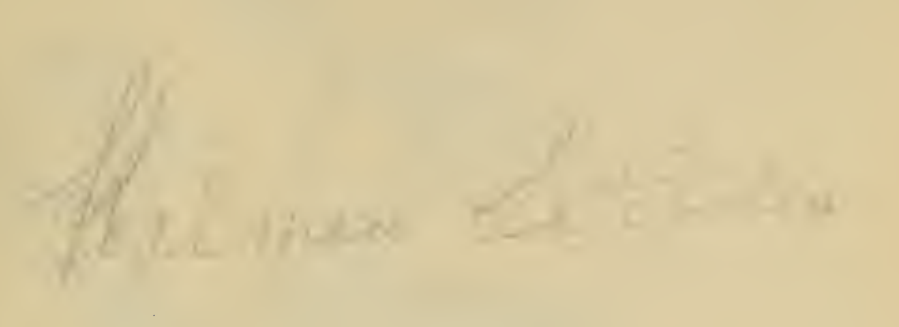


Plate XI.

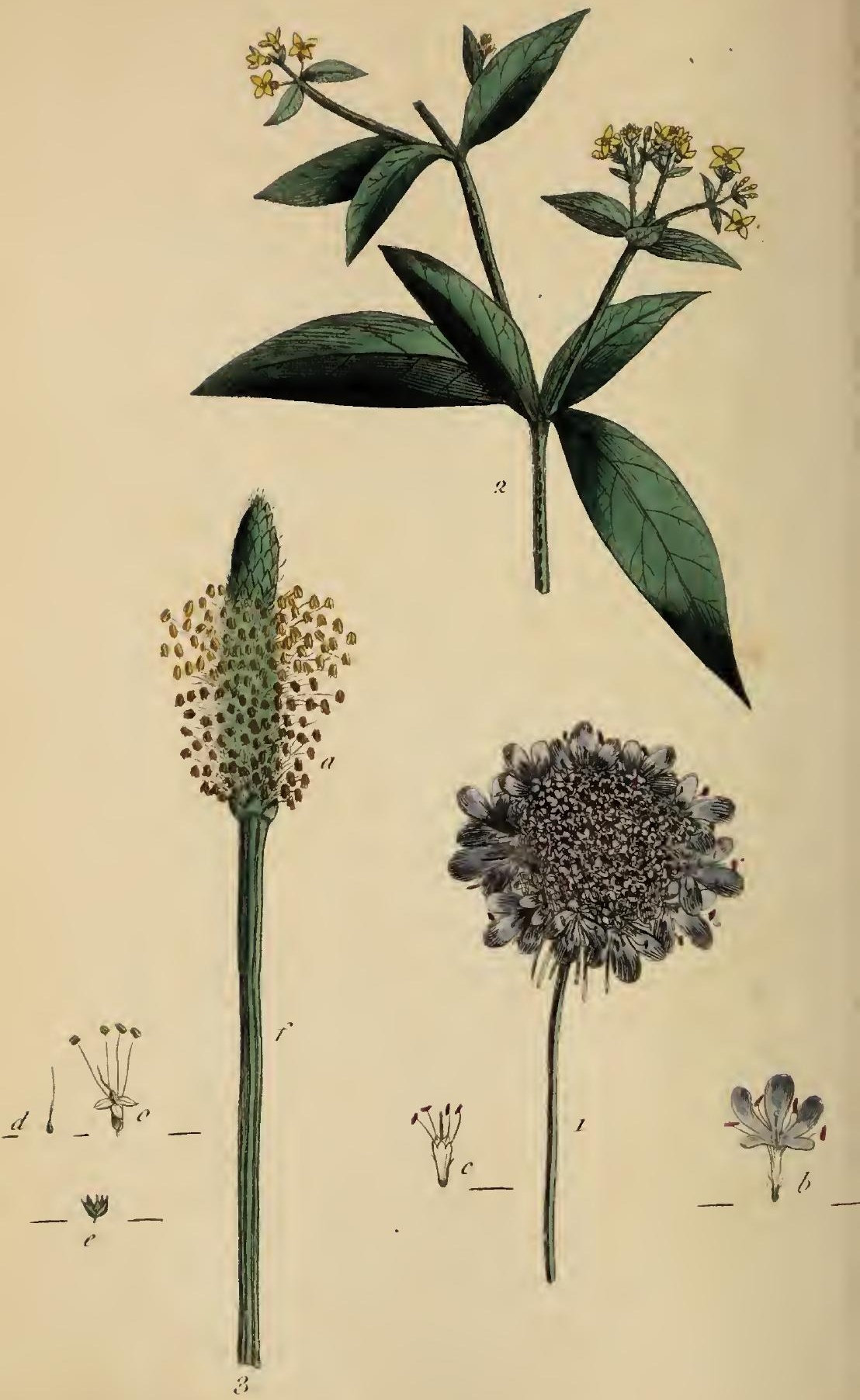




\section{( 21$)$}

\section{PLATE XI. LETTER XV.}

TETRANDRIA.

Fig. 1. Scabiosa columbaria. Small Scabious. An aggregate flower, consisting of many floscules.

b A single floscule; the corolla cut into five irregular segments, and the germ crowned with hairs.

c The calyx, with the four stamens and the pistil.

Fig. 2. Rubia peregrina. Wild Madder.

An instance of stellated plants.

The square stalk: the stellated leaves: the corolla of four segments: the double germ below the flower.

Fig. 3. Plantago lanceolata. Ribwort Plantain.

a The flowers growing in a spike or oblong head. 


\section{(. 22$)$}

$f$ The angular scape.

$o$ A single flower, exhibiting the quadrifid corolla and the very long filaments.

$d$ The germ and style.

$e$ The calyx, inclosing the capsule. 


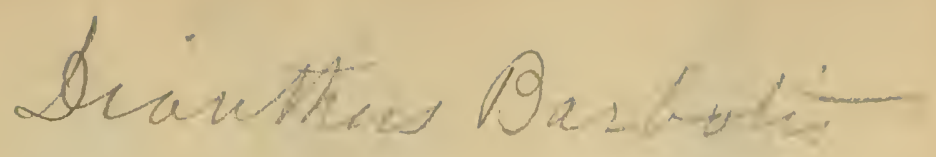

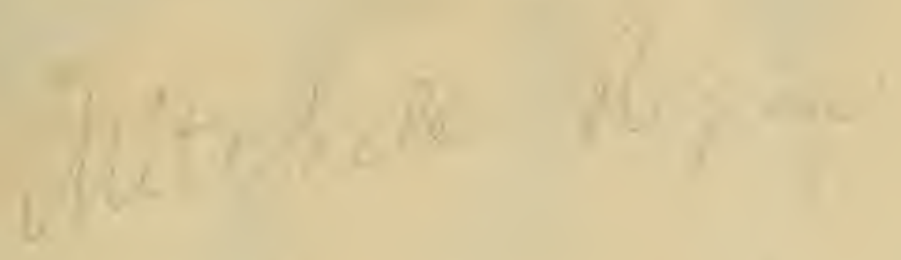




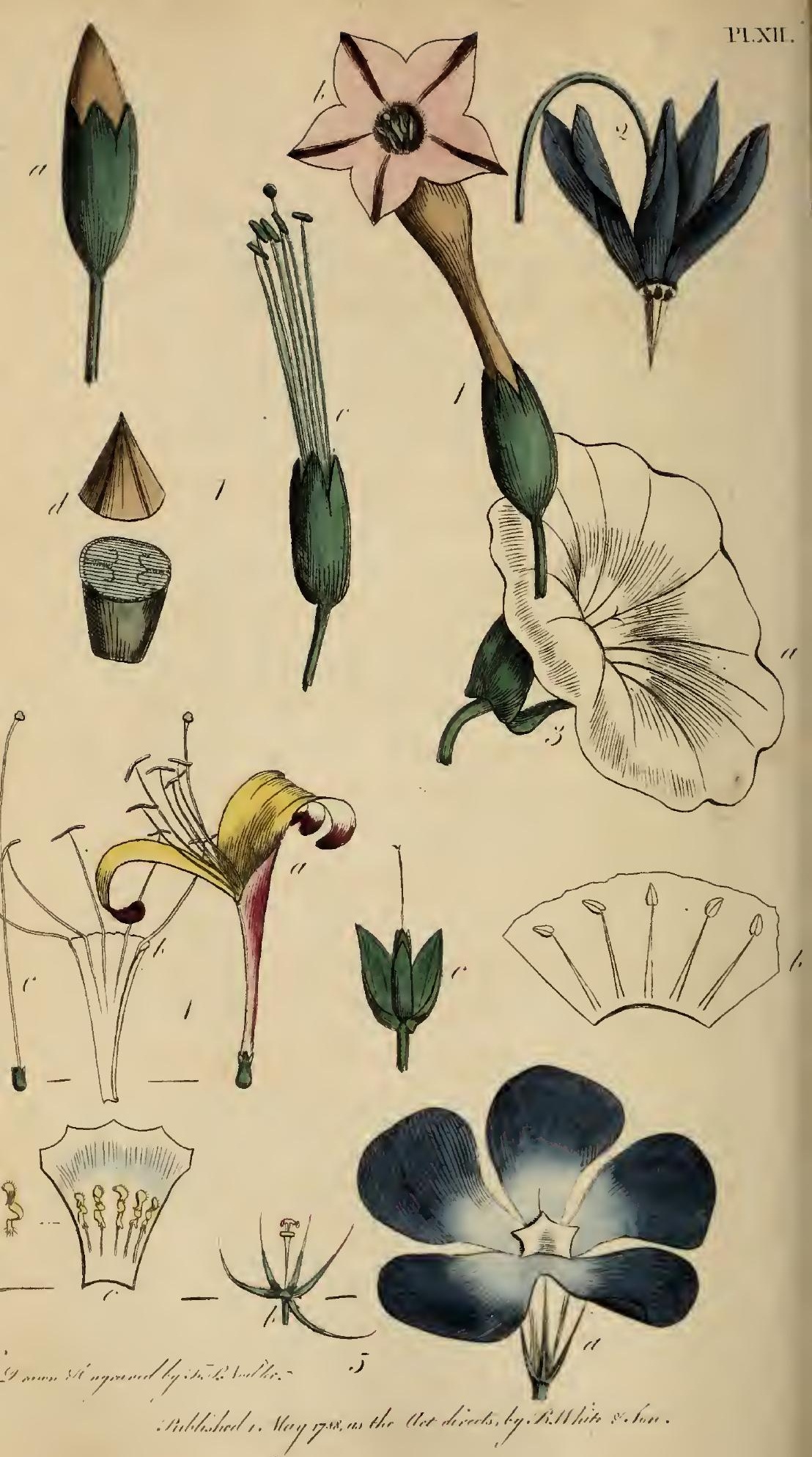




\section{( 23 )}

\section{PLATE XII. LETTER XVI.}

\section{PENTANDRIA MONOGYNIA.}

Fig. 1. Nicotiana Tabácum. Common Tobacco.

a A flower-bud.

$b$ A flower, shorving the funnel-shaped corolla displayed.

c The corolla removed, to show the five stamens and pistil.

d A transverse section of the capsule.

Fig. 2. A flower of Dodecatheon Meadia.

Fig. 3. Convolvulus sepium. Great BindWeed.

a The corolla, with the involucre immediately below it, at Fig. 3.

$b$ The five stamens displayed.

c The germ within the calyx, with the style, terminated by the two stigmas. 


\section{$(24)$}

Fig. 4. Lonicera Caprifolium. Garden Honeysuckle.

a A flower, exhibiting the irregular monopetalous corolla.

$b$ The tube opened, to show the manner in which the filaments are fixed.

c The pistil.

Fig. 5. Vinco major. Great Periwinkle.

a The corolla, showing the bending of its five divisions, and the pentagon form of the faux, or opening of the tube.

$b$ The calyx divided to the bottom into five segments; and the pistil with two stigmas, one over the cther.

c The tube of the corolla opened, to show the situation of the five stamens and form of the anthers.

a A single stamen separate. 


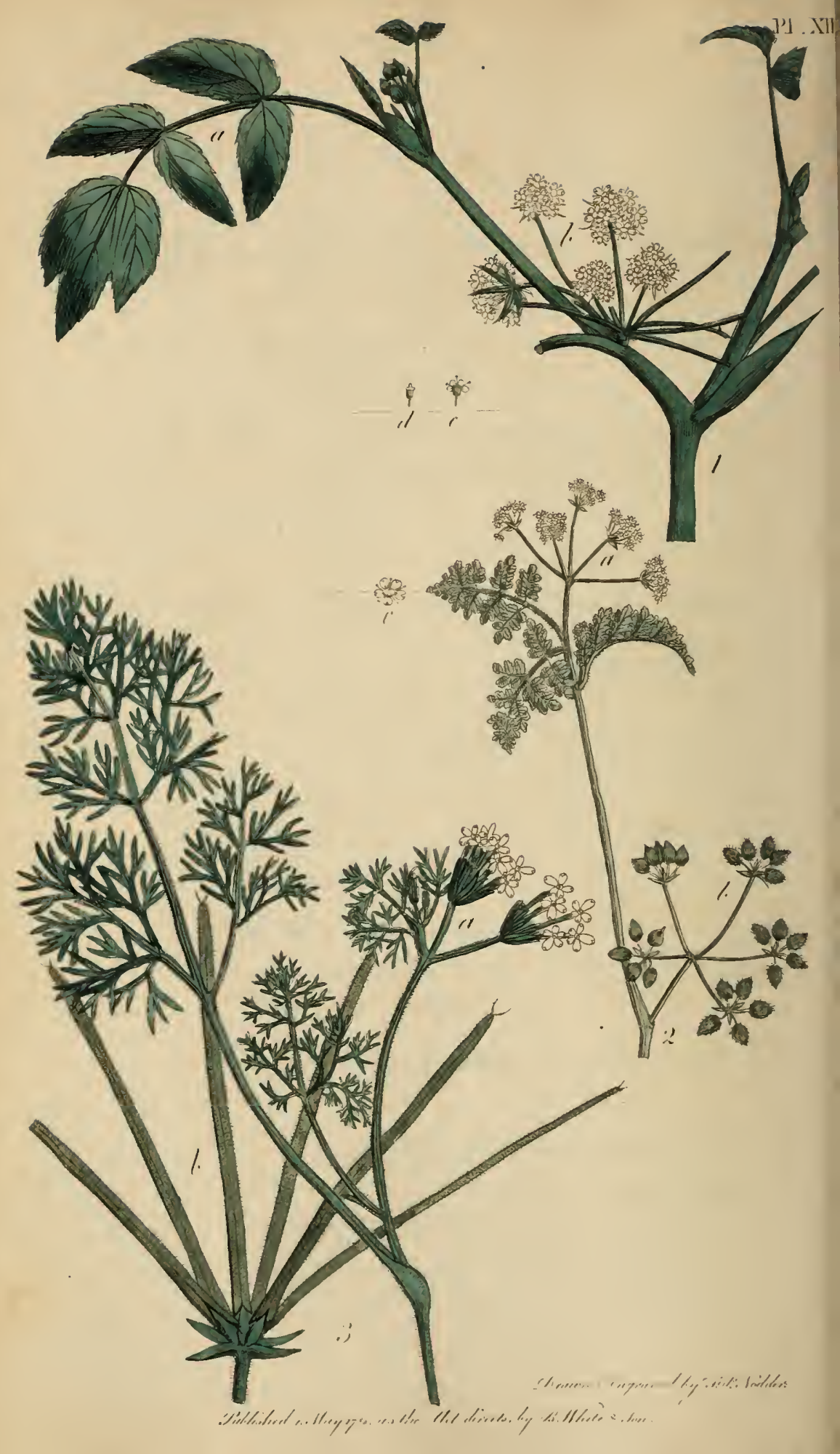


\section{( 25$)$}

\section{PLATE XIII. LETTER XVII.}

PENTANDRIA DIGYNIA.

Fig. 1. Sium nodiflorum. Creeping Water Parsnep.

To show the difference between this plant and water cresses, represented in Plate XXI.

a A pinnated leaf, the pinnæ, small or component leaves, longer and narrower than those of water cresses, serrated on the edges and pointed at the end; the terminating pinna trifid.

$b \quad$ A sessile umbel of flowers.

c A single flower. $-d$ The fruit.

Fig. 2. Scandix Anthriscus. Hemlock Chervil. To show the difference between that and Garden Chervil. Plate 5, Fig. 3.

$a$ An umbel of flowers.

$b$ An umbel of fruits. 


\section{( 26$)$}

Fig. 3. Scandix Pecten. Shepherd's Needle, or Venus's Comb.

a The umbels, being instances of a simple umbel.

$b$ The seeds, terminated by the long processes or beaks, which gave occasion to the names. 


\section{( 27$)$}

\section{PLATE XIV. LETTER XVIII.}

\section{HEXANDRIA.}

Fig. 1. Tradescantia Virginica. Virginian Spiderwort.

a The corolla of three petals.

$b \quad b$ The three-leaved calyx.

c One of the fringed filaments.

d The pistil.

Fig. 2. Narcissus Tazetta. Polyanthus Narcissus.

a The corolla in front, showing the six equal petals, and the funnel or cup-shaped nectary.

$b$ A back view of the flower, showing that the corolla is superior, or on the top of the germ.

c The spathe.

$d$ The corolla opened, to show the situation of the six stamens within the nectary.

e The pistil. 


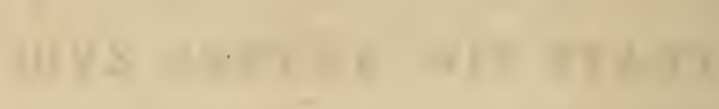



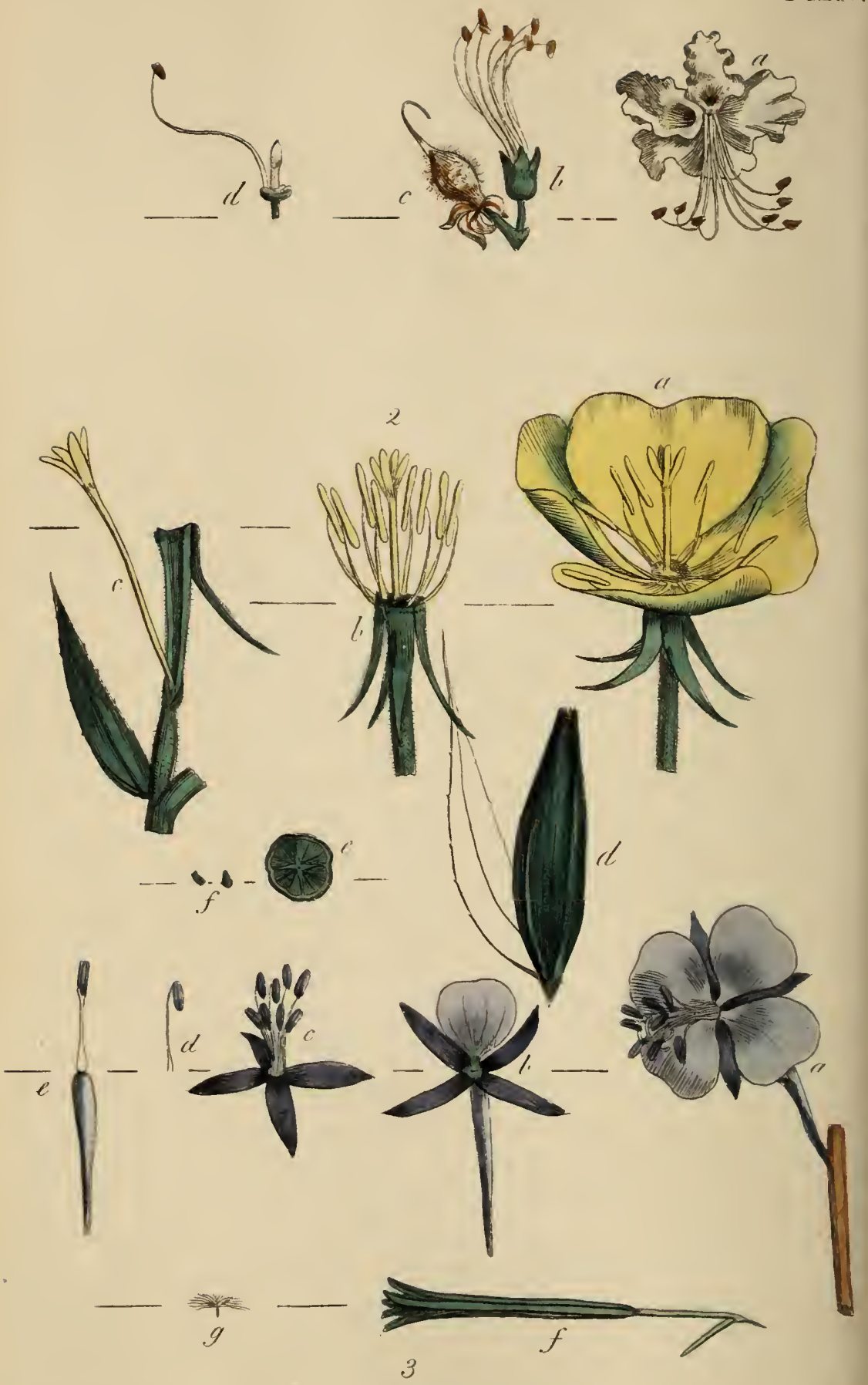

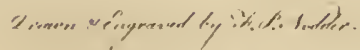

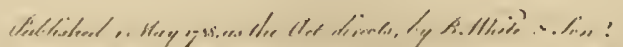




\section{( 29$)$}

\section{PLATE XV. LETTER XIX.}

\section{HEPTANDRIA.}

Fig. 1. Asculus Hippocastanum. Horse Chesnut.

a The corolla of five petals, and the seven stamens, with bending filaments.

b The one-leafed calyx, swelling at the base, and divided at top into five segments.

c The young capsule terminated by the stylé.

d A single stamen.

$$
\text { OCTANDRIA. }
$$

Fig. 2. Oenothera biennis. Tree Primrose.

a A flower, showing the four-parted calyx, and the corolla of four obcordate petals.

$b$ The eight stamens, and the pistil in the the middle, with deflected calyx.

c The pistil, with the filiform style, and the quadrifid stigma.

d The capsule.

$e$ A transverse section of the capsule, showing the four cells.

$f$ The seeds. 


\section{$(30)$}

Fig. 3. Epilobium angustifolium. French Willow.

a The flower.

$b$ The four-leaved calyx.

c The stamens, four longer and four shorter.

d A single stamen.

$e$ The pistil.

$f$ The capsule.

g A seed crowned with down. 


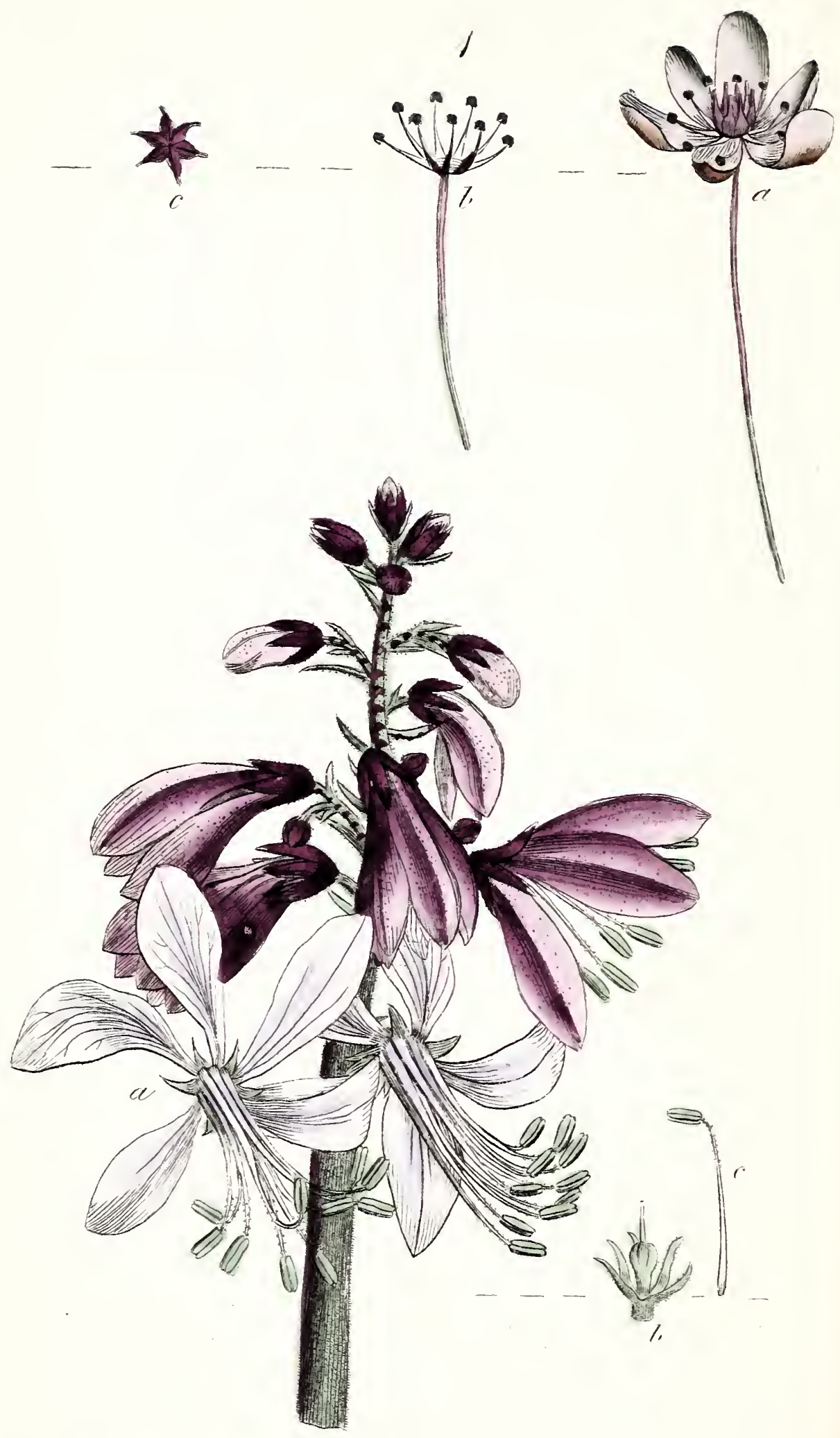

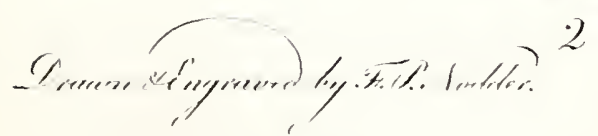

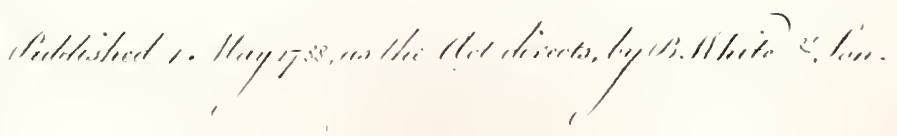




\title{
( 31$)$
}

\section{PLATE XVI. LETTER XIX.}

\author{
ENNEANDRIA HEXAGYNIA.
}

Fig. 1. Butomus umbellatus. Pllowering Rusho.

a The flower of six petals.

$b$ The nine stamens.

c The six capsules.

\section{DECANDRIA MONOGYNIA.}

Fig. 2. Dictamnus albus. Fraxinella.

a The flower, with a corolla of five spreading petals.

$b$ The five-leaved calyx, with the capsules.

c A single filament, with its glandules. 

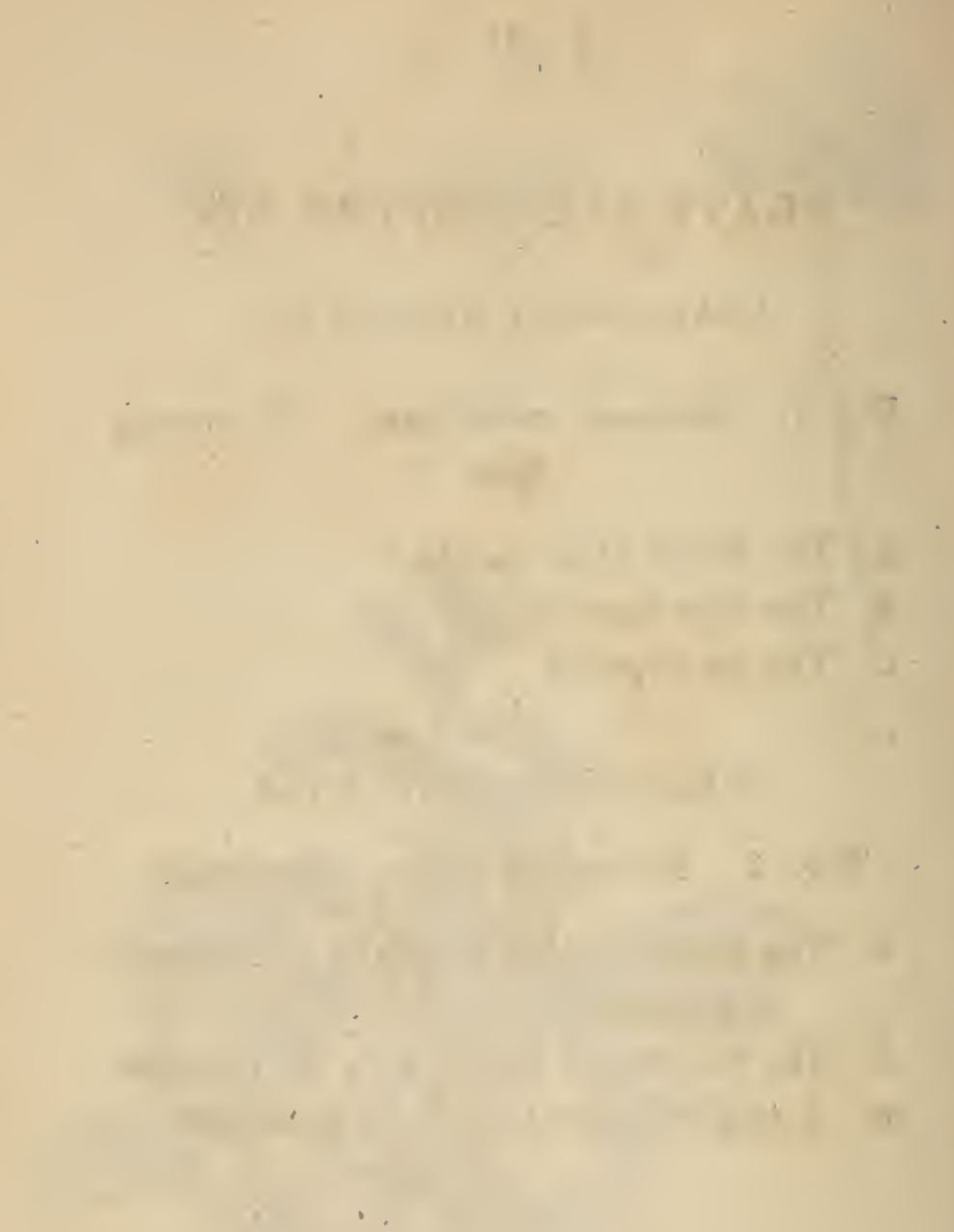


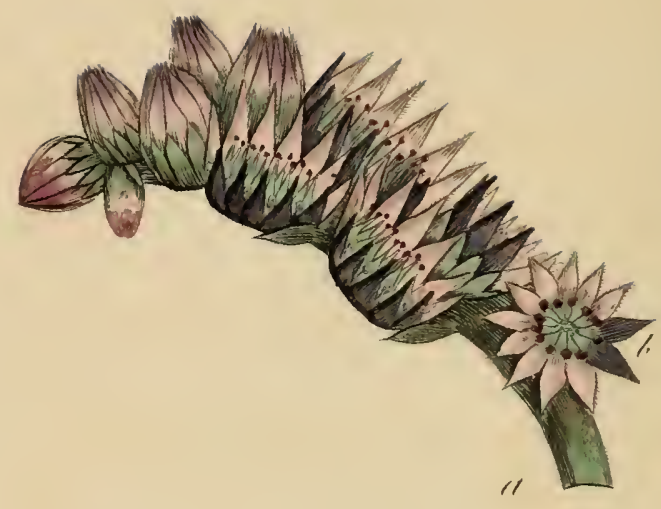

$-\frac{1}{2}-1+4$

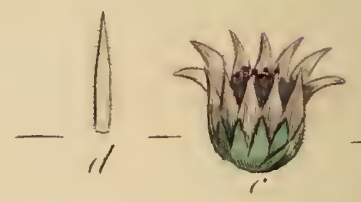




\section{( 33 )}

\section{PLATE XVII. LETTER XX.}

DODECANDRIA DODECAGYNIA.

Sempervivum tectorum. Common Houseleek.

a The flower-stem, with a reflexed range of flowers.

$b$ A flower in front, showing the corolla of twelve petals.

c The calyx, with the capsules, after the flower is past.

$d$ A single capsule.

$e$ The twelve stamens and twelve styles, separated from the flower.

$f$ A single pistil, exhibiting the germ, style, and anther.

g. Two stamens. 

ㄴ. X广III.

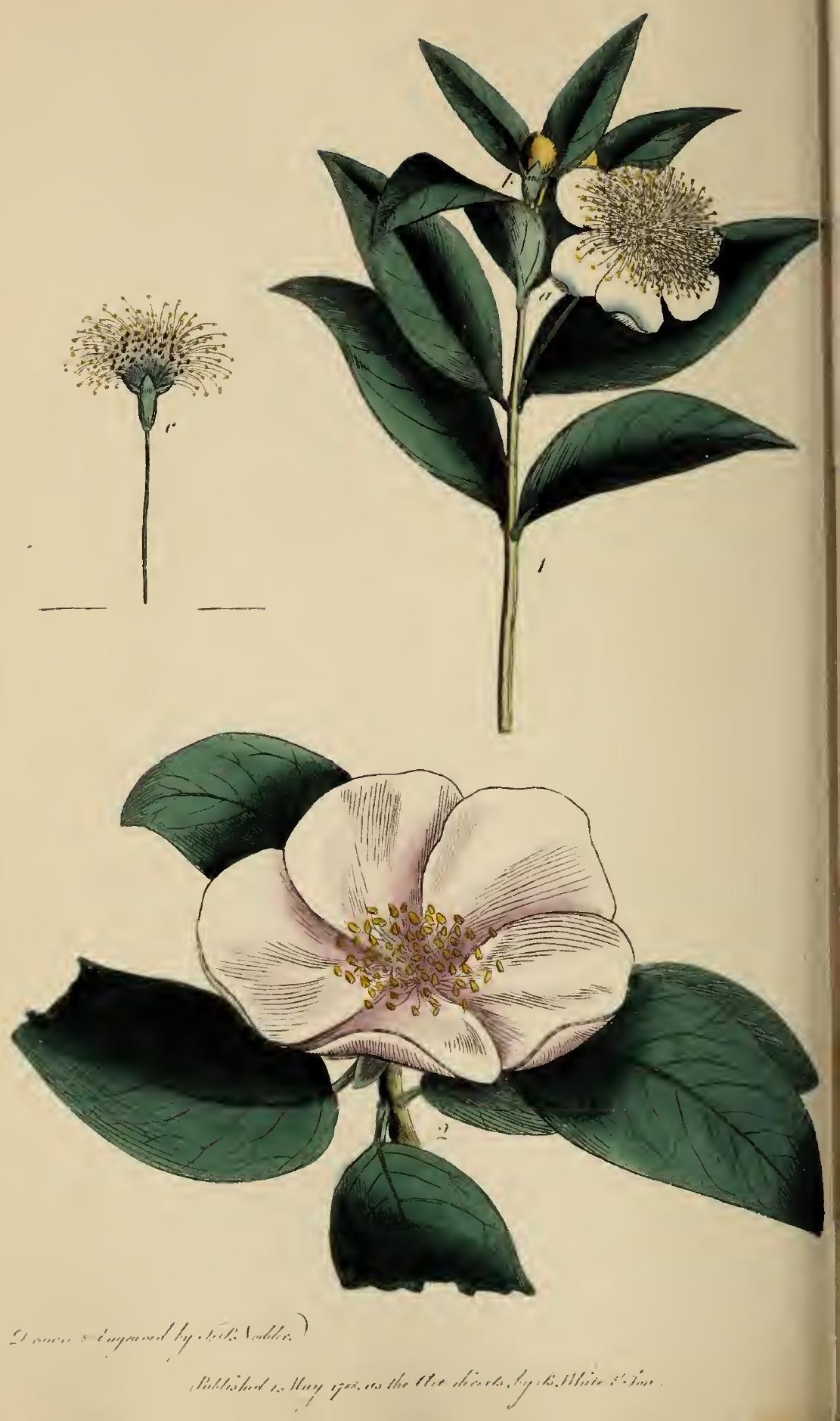




\title{
( 35$)$
}

\section{PLATE XVIII. LETTER XXI.}

\author{
ICOSANDRIA.
}

Fig. 1. Myrtus communis. Common Myrtle.

$a$ The corolla.

$b$ The fruit or berry.

c A single flower without the corolla, showing the stamens proceeding from the calyx.

Fig. 2. Pyrus Cydonia. The Quince. 

PIXIX.
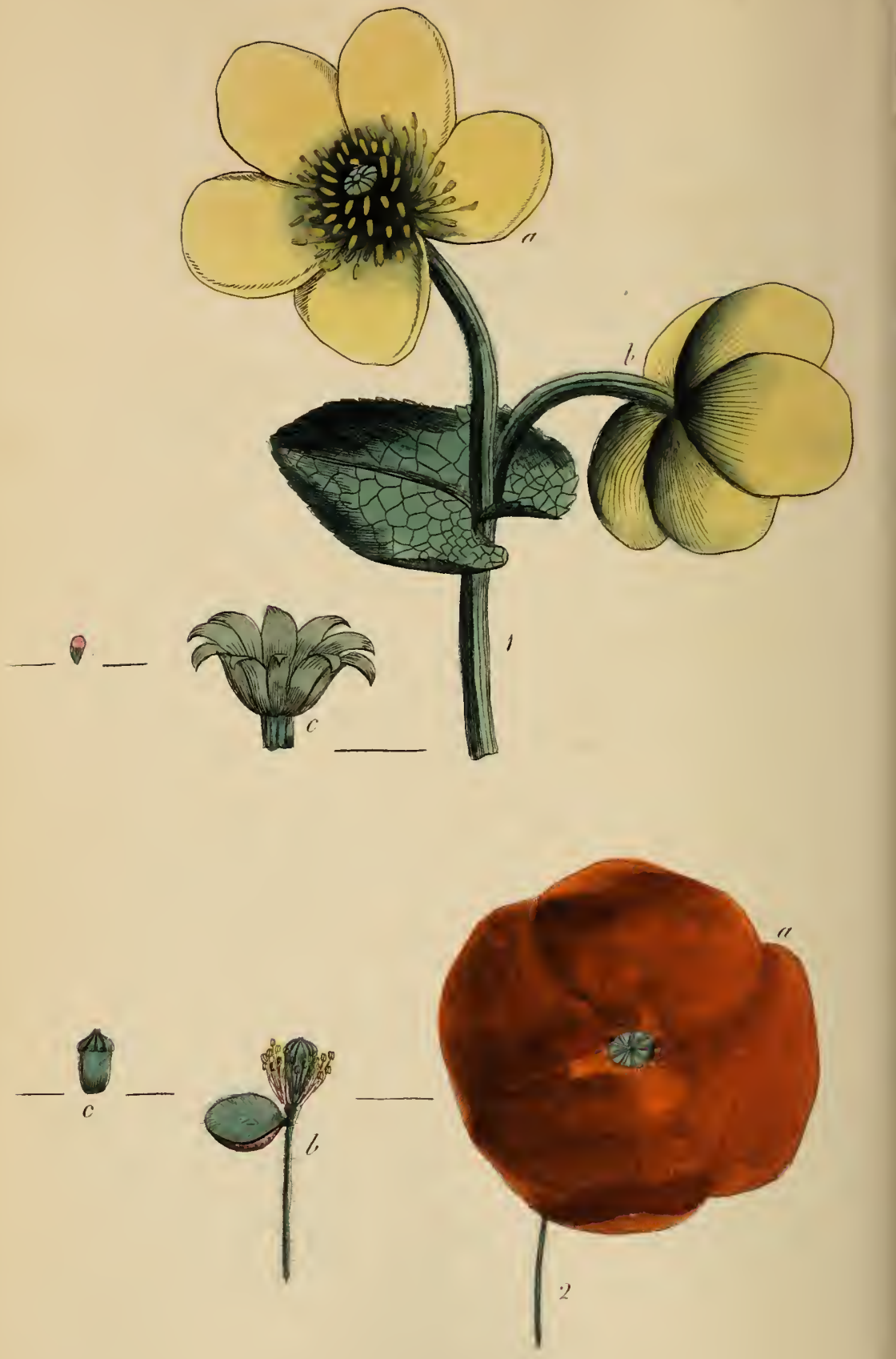

ann

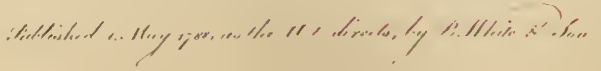




\title{
( 37$)$
}

\section{PLATE XIX. LETTER XXI.}

\author{
POLYANDRIA.
}

Fig. 1. Caltha palustris. Marsh Marigold.

a A flower, showing the corolla of five petals, the many stamens shorter than the corolla, \&c.

$b$ Another flower, showing that it has no calyx.

$\varepsilon$ The capsules, after the flower is past.

Fig. 2. Papaver Rhoeas. Corn Poppy.

a The corolla of four large roundish petals.

$b$ The numerous stamens proceeding from the receptacle.

$\varepsilon$ The capsule crowned with its stigma.

Obs. Fig. 1. is an instance of the order Polygynia.

Fig. 2. of the order Monogynia. 



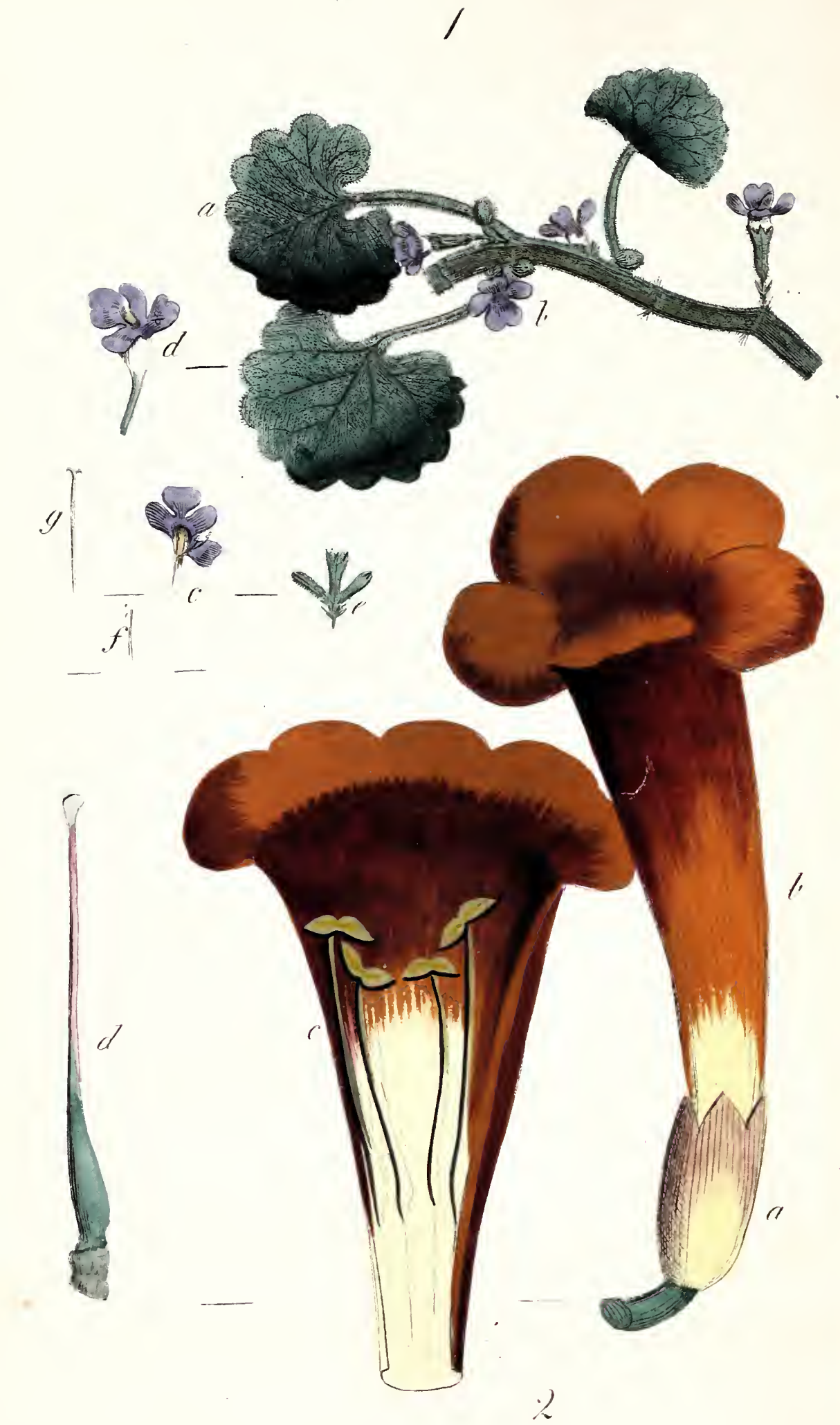

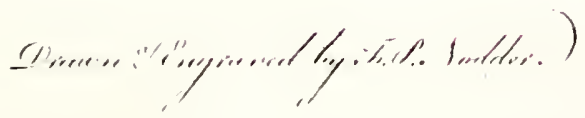

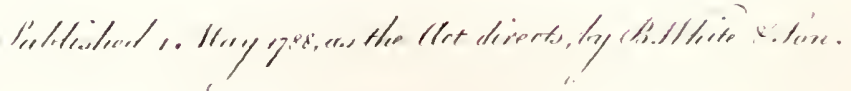




\section{$(39)$}

\section{PLATE XX. LETTER XXII.}

DIDYNAMIA GYMNOSPERMIA.

Fig. 1. Glechoma hederacea. Ground Ivy.

a The kidney-shaped leaves.

$b$ The ringent flowers.

c A flower opened, to show the situation of the stamens.

d A flower exhibiting the cruciform appearance of the anthers.

$e$ The calyxes.

$f$ A single filament.

$g$ The pistil.

DIDYNAMIA ANGIOSPERMIA.

Fig. 2. Bignonia radicans. Trumpet Flower.

a The calyx.

$b$ The corolla.

c The corolla displayed, to show the situation of the stamens.

$d$ The pistil.

Obs. The classical character is clearly shown at Fig. 2. $c$.

This class was farther illustrated in Plate IV. 



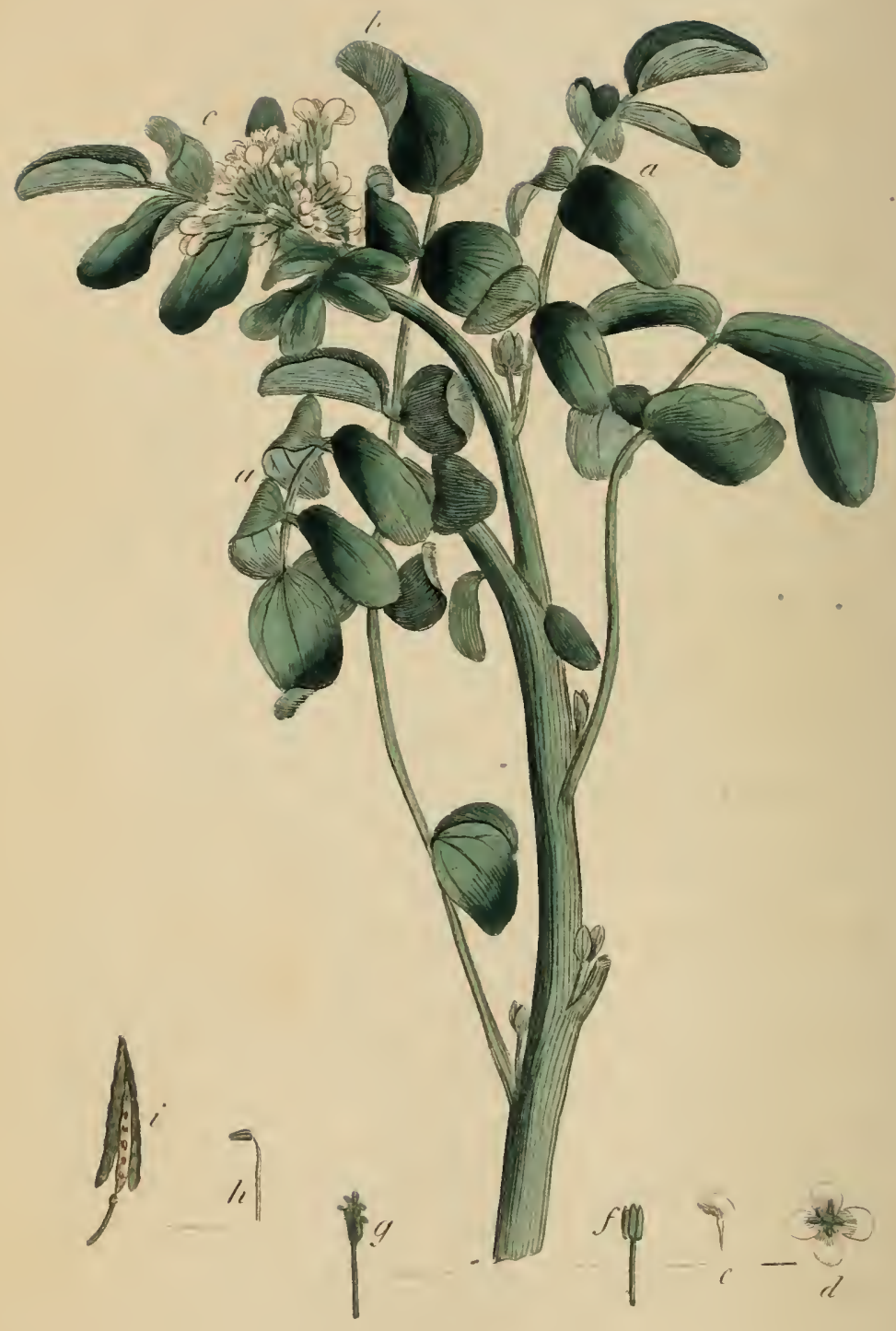




\section{( 41$)$}

\section{PLATE XXI. LETTER XXIII.}

TETRADYNAMIA.

Sisymbrium Nasturtium. Water Cress.

a a The pinnated leaves.

$b$ The odd lobe ending blunt.

$c$ The corymb of flowers.

d A single four-petalled cruciform flower.

$e$ A single petal.

$f$ The calyx.

$g$ The calyx, with the stamens.

$h$ A single stamen.

$i$ The silique.

Compare Plate XIII. See also Plate II. 


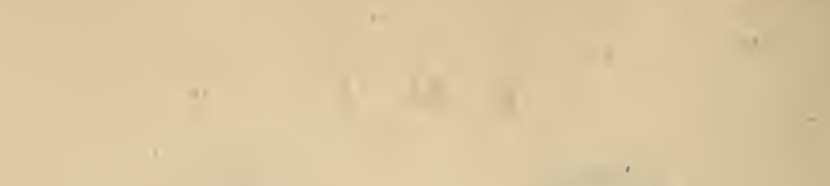

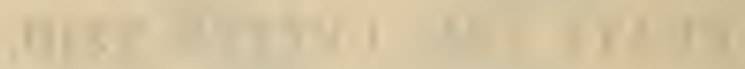

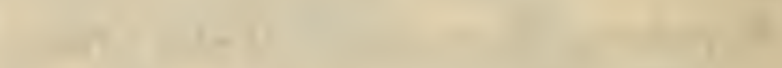

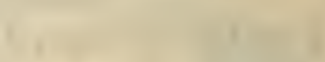

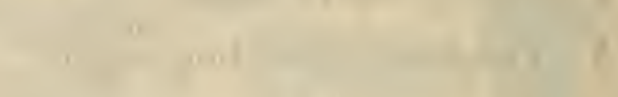

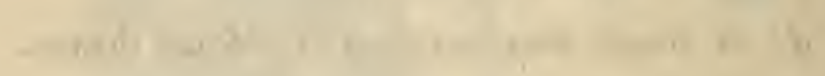$$
\text { 1 }
$$

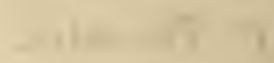$$
1
$$

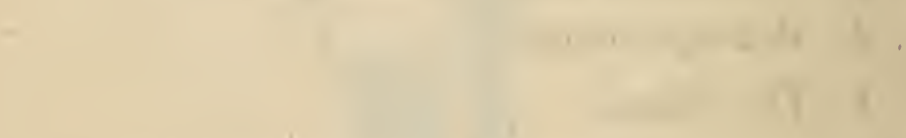

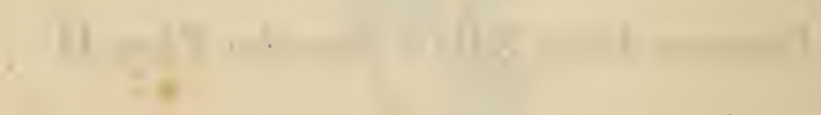


$\int_{c}^{1}+\frac{1}{T_{6}}$
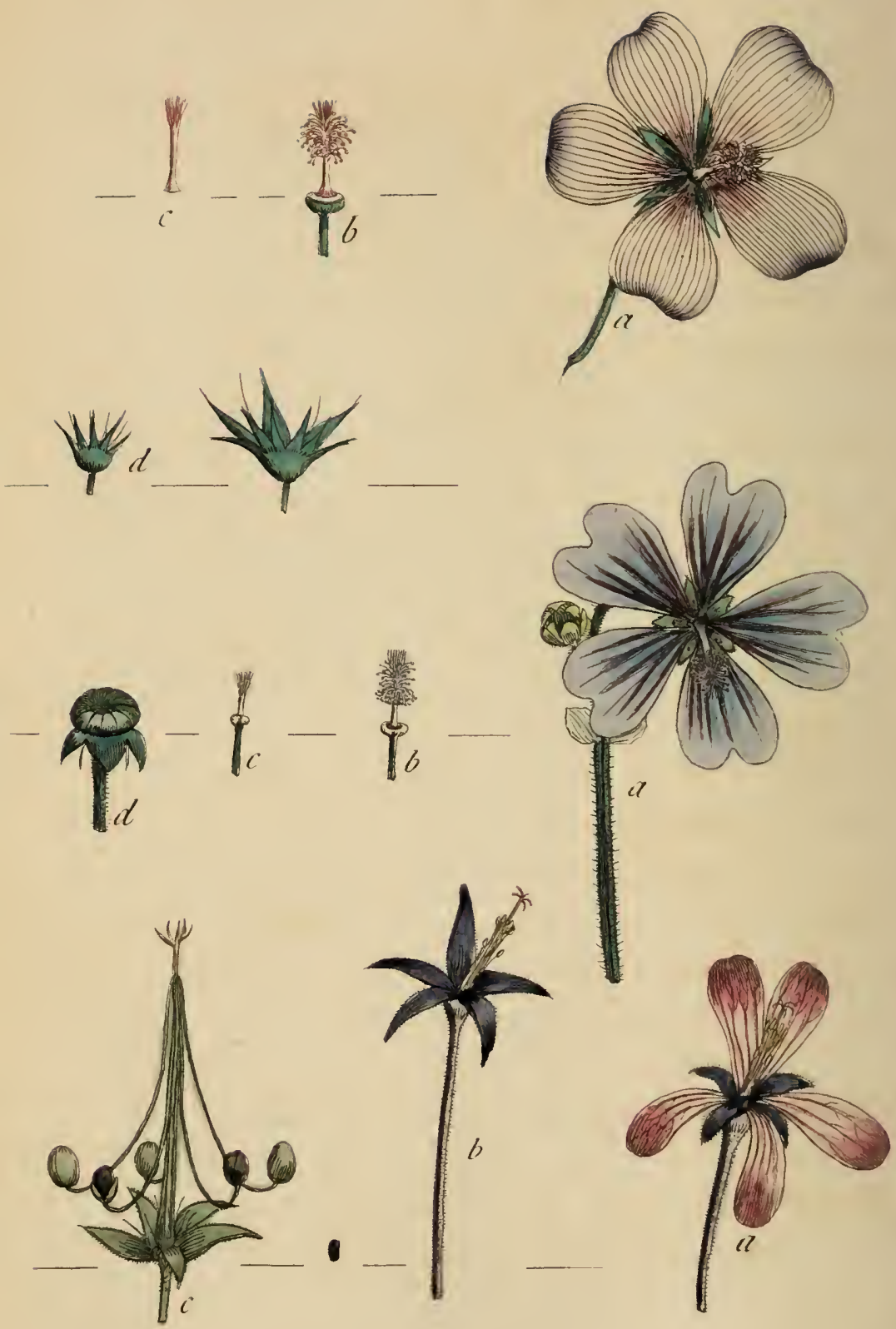


\section{( 43$)$}

PLATE XXII. LETTER XXIV.

MONADELPHIA.

Fig. 1. Althæa officinalis. Mar'sh Mallow.

a The flower, showing the five petals united at bottom, obcordate or inversely heart-shaped, and slightly emarginated or end-nicked. In the centre is the column of stamens, with the pistils in the middle of them.

$b$ The column of stamens and pistils removed from the corolla, and showing the rudiment of the fruit underneath.

c The pistil separate.

d The calyx, exhibiting the nine divisions of the outer calyx, which is one of the principal generic characters.

Fig. 2. Malva sylvestris.' Common Mallow. a The flower as before. The petals narrow, heart-shaped, and much more deeply end-nicked.

$b c$ The column of stamens, and pistil separated.

d The fruit, with the double calyx; the outer very narrow, the clefts of the 


\section{( 44$)$}

inner broad and large: there are five of these, and three distinct leaves in the other; but all of them could not be represented. The fruit flat, with many seeds in a ring, each covered with its aril, or loose coat.

Fig. 3. Geranium zonale. Horse-shoe Cranesbill.

it The flower, showing the corolla of five unequal petals, with the column of stamens, very slightly connected at bottom, and of unequal lengths.

b The calyx, with the column of stamens. Both these figures show the style standing up above the stamens, and terminated by five stigmas.

c The fruit, with the permanent style and stigmas; showing the beaked form of it, and the five seeds in their arils, each terminated by a tail, and separating from the beak. $a b c$ show that the calyx is single and five-leaved.

N. B. These figures serve to explain the class Monadelphia: and two of the orders, Decandria, Fig. 3, and Polyandria, Fig. 1, 2. 


\section{( 45$)$}

\section{PLATE XXII. LETTER XXV.}

DIADELPIIIA DECANDRIA.

Lathyrus latifolius. Everlasting $\boldsymbol{P} e \boldsymbol{a}$.

Fig. 1. A bunch of flowers, in their natural size and situation.

Fig. 2. The banner.

Fig. 3. One of the wings.

Fig. 4. The keel.

Fig. 5. The stamens and pistil in their natural situation.

Fig. 6. The stamens, showing the simple filament separate from the compound one.

Fig. 7. The pistil.

See Plate III. 




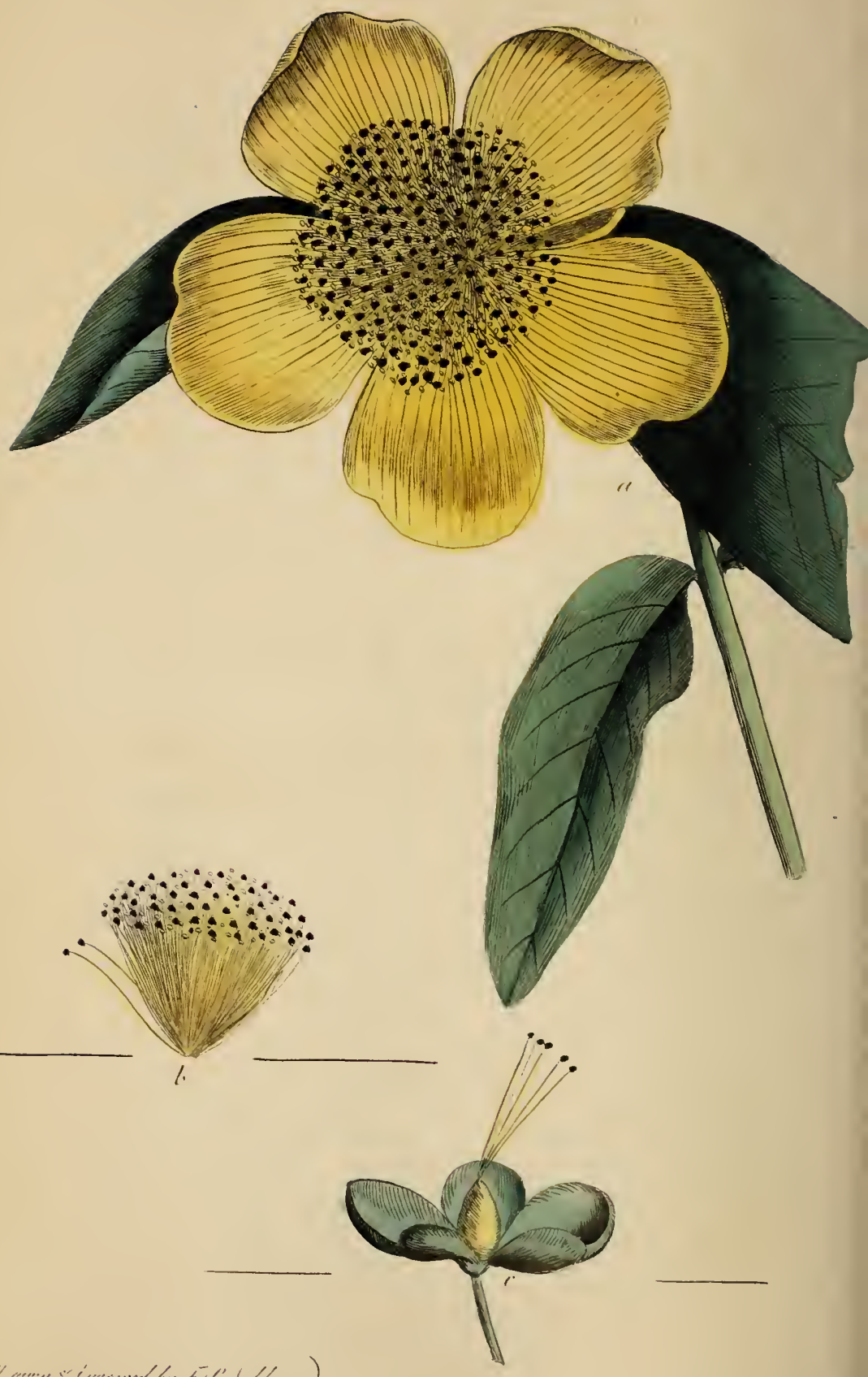




\section{( 47$)$}

\section{PLATE XXIV. LETTER XXV。}

\section{POLYADELPHIA.}

Hypericum Ascyron. Garden Tutsan.

a The flower, with a corolla of five petals and the numerous stamens in the middle.

$b$ A single pencil or parcel of stamens.

c The permanent five-parted calyx, including the germ terminated by five pistils.

d Explains the characters of the class and order-Polyadelphia Polyandria. 




\section{( 49 )}

\section{PLATE XXV. LETTER XXVI.}

SYNGENESIA POLYGAMIA AE UALIS.

Fig. 1. Tragopogon porrifolium. Salsafy.

a A flower closed, showing the simple calyx.

$b$ A single ligulate floscule.

c A floscule, deprived of the corolla.

$d$ A seed, with the feathered stipitate down.

$e$ The cylinder of anthers, with the pistil perforating it, terminated by the two revolute stigmas.

$f \quad$ The cylinder of anthers alone.

Fig. 2. Carduus nutans. Musk Thistle.

$a$ The compound flower, showing the calyx all imbricate with thorny scales.

$b$ A front view of the whole compound Hower, composed wholly of tubulous florets.

c A single floscule or floret.

$d$ The cylinder of anthers.

$e$ The pistil. 


\section{$(50)$}

Fig. 3. Eupatorium cannabinum. Common Hemp Agrimony.

a A bunch of flowers.

$b$ A single flower.

c A single bunch of flowers.

d The down.

Obs. These three figures explain the three sections of this order. 1. Containing compound flowers with ligulate florets only. 2. The capitate or headed flowers, with tubulous florets only. 3. The discoid, or naked discous flowers, with tubulous florets, but not in a head. 
Plate XXVI.

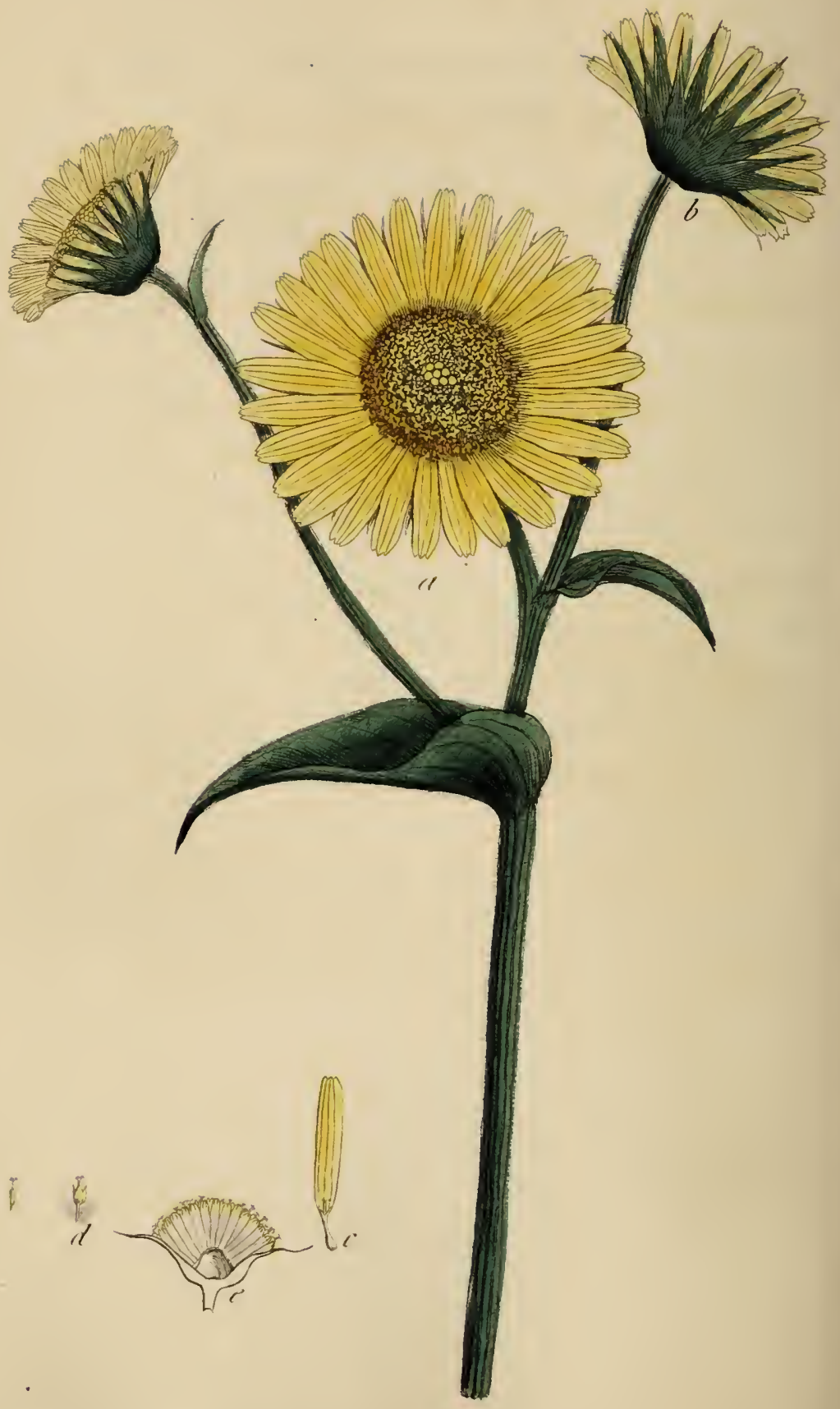




\section{( 51$)$}

\section{PLATE XXVI. LETTER XXIV.}

SYNGENESIA POLYGAMIA SUPERFLUA.

Doronicum pardalianches. Common Leopard's Bane.

a The compound radiated flower, consisting of regular tubulous floscules in the disk, and irregular ligulate floscules in the ray.

$b$ The under part of the flower, showing the double row of scales to the calyx.

$c$ One of the semi-florets, or ligulate floscules, taken from the ray, to show that the seed is naked, or destitute of down.

$d$ A floret from the disk, the seed of which is crowned with a simple down.

$e \quad$ A section of the disk, in order to exhibit the naked receptacle. 

P'I. XIII.
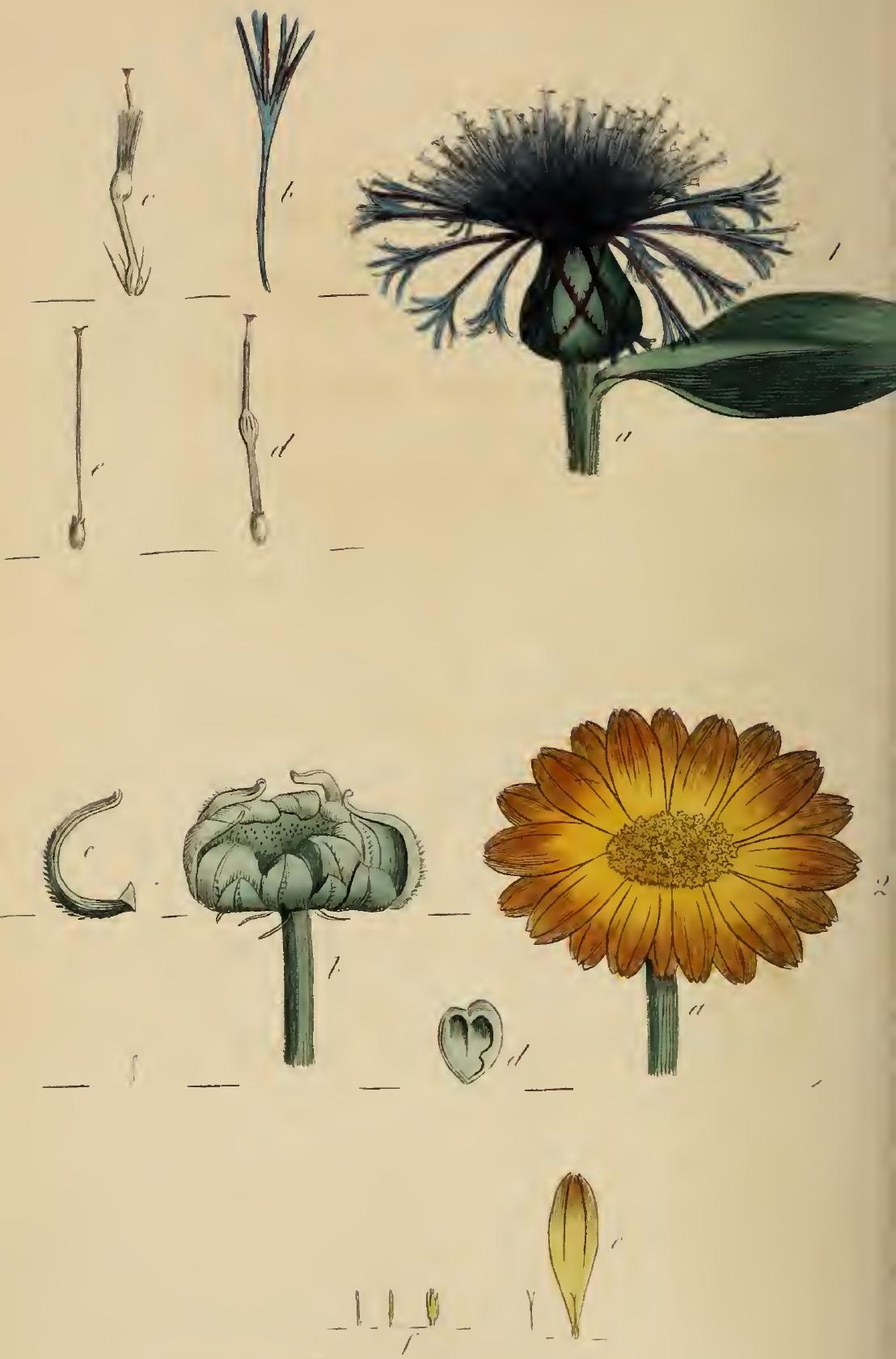

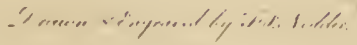




\section{( $53 /)$}

\section{PLATE XXVII. LETTER XXVI.}

SYNGEN. POLYG. FRUSTRANEA

and NECESSARIA.

Fig. 1. Centaurea montana. Mountain Blue Bottle.

a The compound flower, showing the neutral or barren florets on the outside, longer than the fertile ones in the middle, and the ciliated scales of the calyx.

$b$ A barren floret.

c A fertile floret, with some of the bristles at the base.

$d$ The same, divested of the corolla.

$e$ The pistil.

N. B. This serves to explain the order Polygamia Frustranea in the class Syngenesia.

Fig. 2. Calendula officinalis. Garden Marigold.

a The compound radiated flower.

$b$ The calyx, with the seeds in the ray only, bending inwards after the florets are decayed. 


\section{( 54$)$}

c The boat-shaped muricated seed, without down.

d A barren seed, from one of the central flowers.

e A fertile floscule from the ray.

$f$ A barren floscule from the disk.

N. B. This serves to explain the order Polygamia Necessaria in the class Syngenesia. 
. 


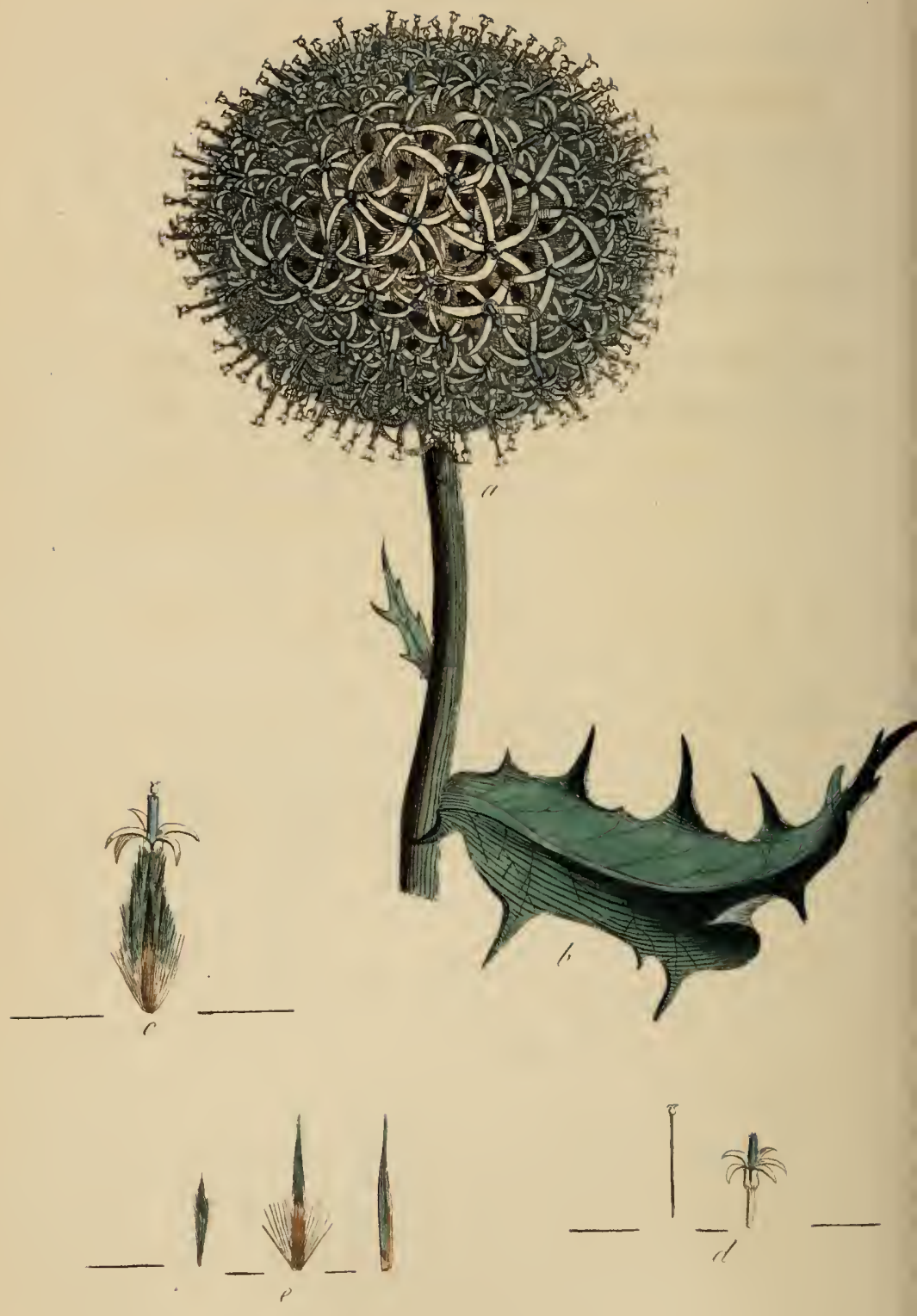




\section{$(55)$}

\section{PLATE XXVIII. LETTER XXVI.}

SYNGEN. POLYG. SEGREGATA.

Echinops sphærocephalus. Globe Thistle.

$a$ The entire compound flower, consisting of tubular florets, separated by their proper perianths; which determines this plant to be of the segregate order in the class Syngenesia.

$b$ A sinuated leaf, the jags ending in spines.

c A single floscule in its calyx.

d A floscule taken out of the calyx, with the style separate.

e A single subulate leaflet of the calyx, in three different views. 



\section{-}


PI.XXIX.

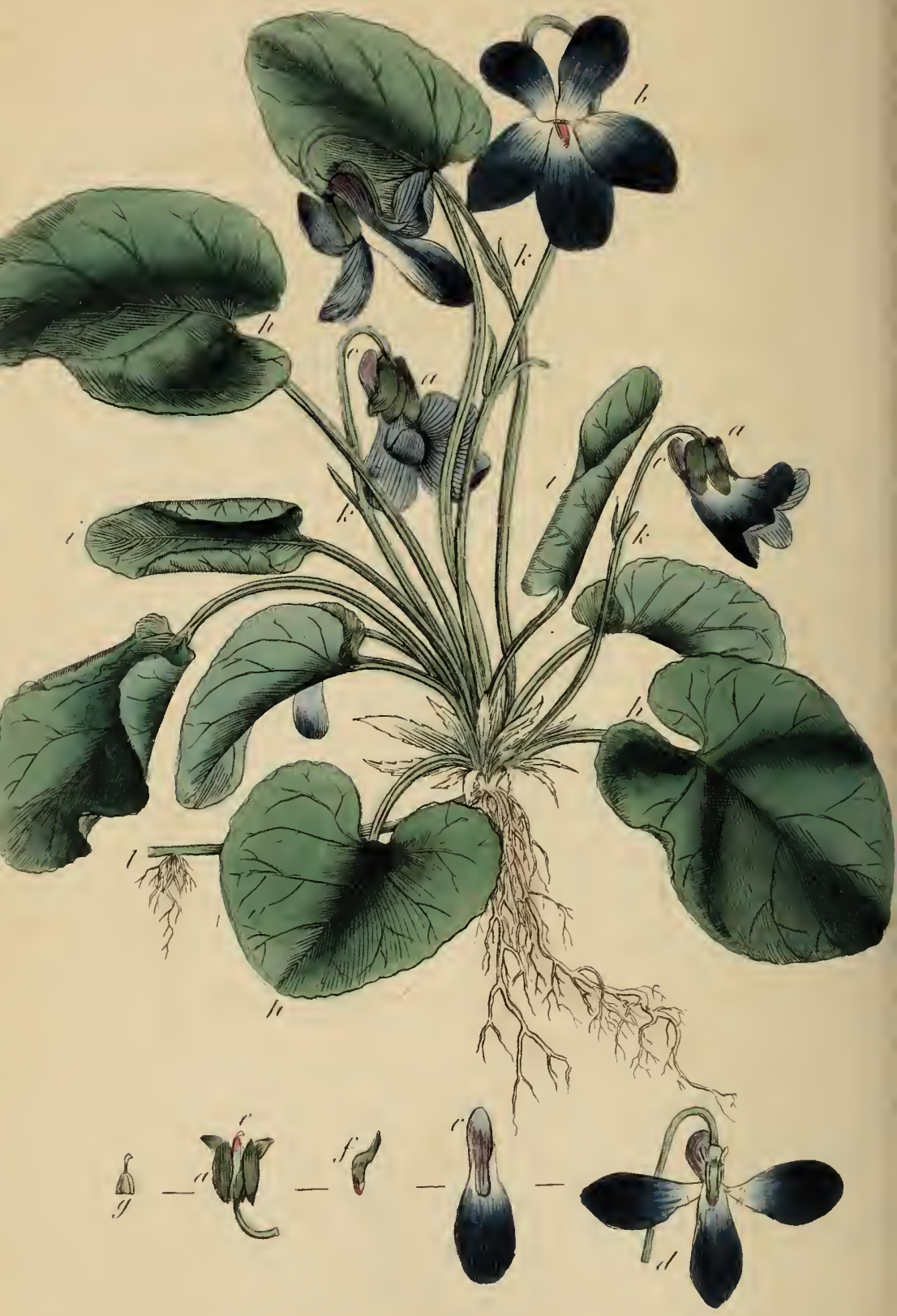

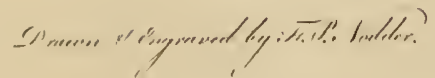

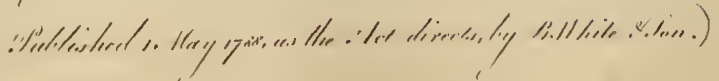




\section{( 57$)$}

\section{PLATE XXIX. LET'TER XXVI.}

\section{SYNGENESIA MONOGAMIA.}

Viola odorata. Sweet Violet.

a The calyx of five leaves.

$b$ The corolla of five irregular petals.

c The horn-shaped nectary.

d A flower opened, to show the stamens with the five connected anthers.

e The stamens within the calyx.

$f$ A single stamen.

$g$ The pistil.

$h h h$ The heart-shaped leaves.

$i i$ The young leaves, involuted, rolled inwards, or rather upwards.

$k k k$ The scape, with the double bracte on the middle of it.

$l$ One of the stolones, or runners, putting forth roots. 
(192) 


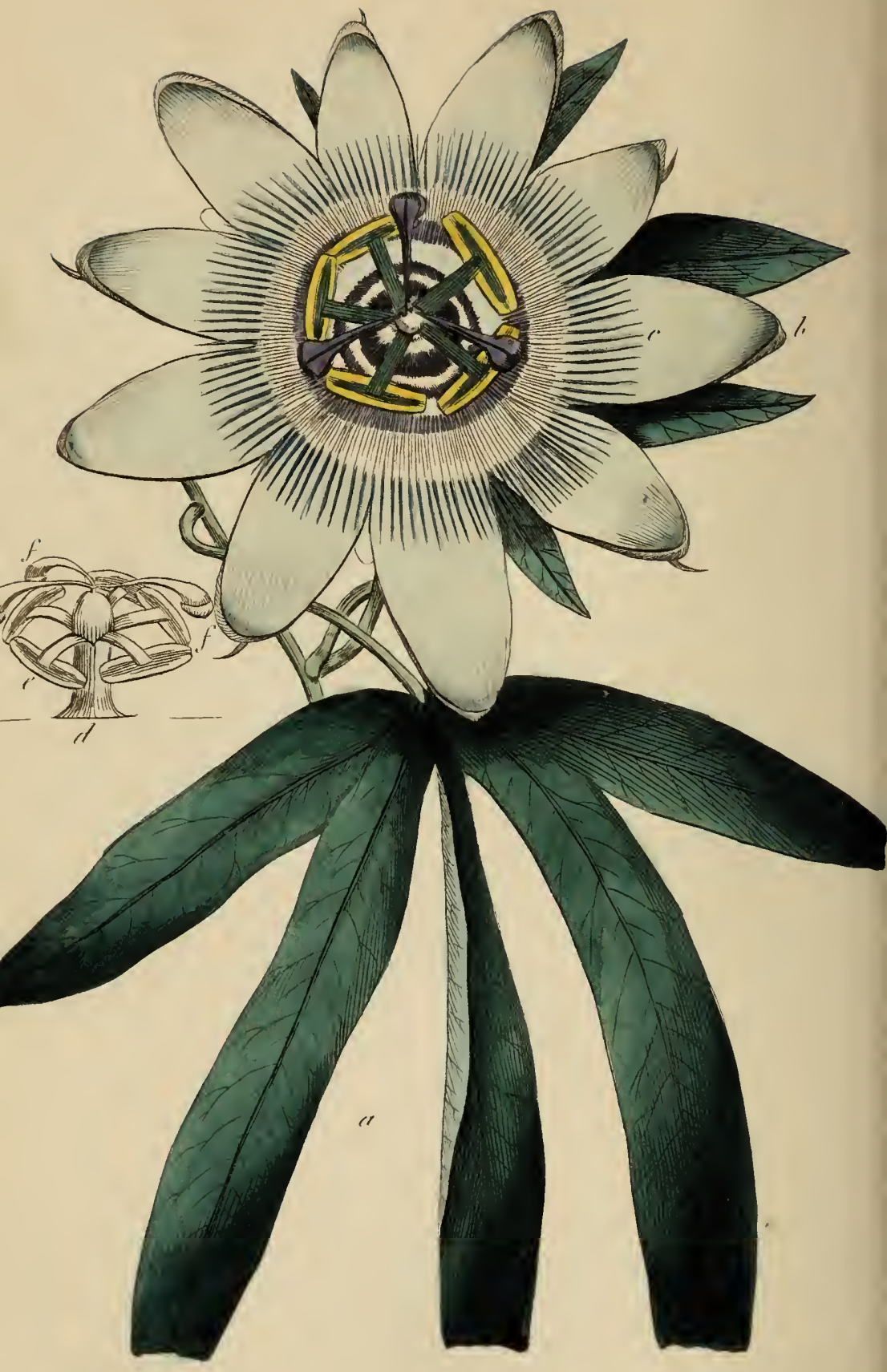




\title{
( 59 )
}

\section{PLATE XXX. LETTER XXVII.}

\author{
GYNANDRIA.
}

Passiflora cærulea. Bhue Passion Flower.

$a$ The palmated leaf.

$b$ The corolla and calyx, each of five leaves, and having the same appearance in front.

c The radiate crown, which is the nectary.

$d$ The pistil and five stamens.

$e$ The anthers terminating the filaments, which spring from the bottom of the germ, where it meets the pedicle, upon which it stands.

$f f f$ The three stigmas arising from the germ. 




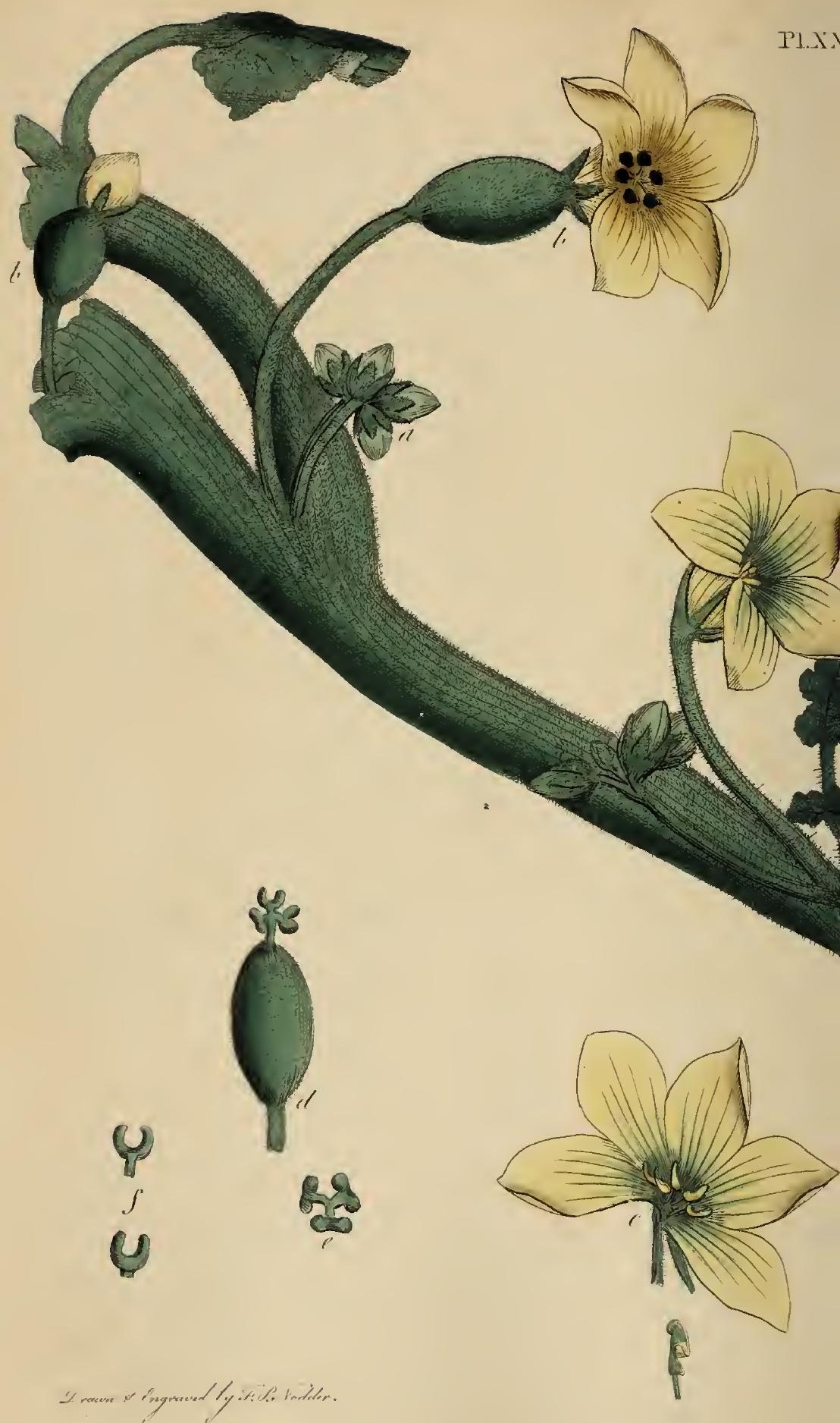




\section{$(61)$}

\section{PLATE XXXI. LETTER XXVIII,}

\section{MONOECIA.}

Momordica Elaterium. Spirting Cucumber.

a $a$ The male or staminiferous flowers.

$b \quad b$ The female or pistilliferous flowers, with the large germ below the receptacle.

c The male flower, showing the three filaments, with double anthers on two of them, and a simple anther on the third.

d The germ, surmounted with the style, divided into three parts, each part sustaining an oblong gibbous stigma.

$e$ The divided part of the style, with the stigmas.

$f$ Two different views of a single stigma. 

1:1 XXXI!.

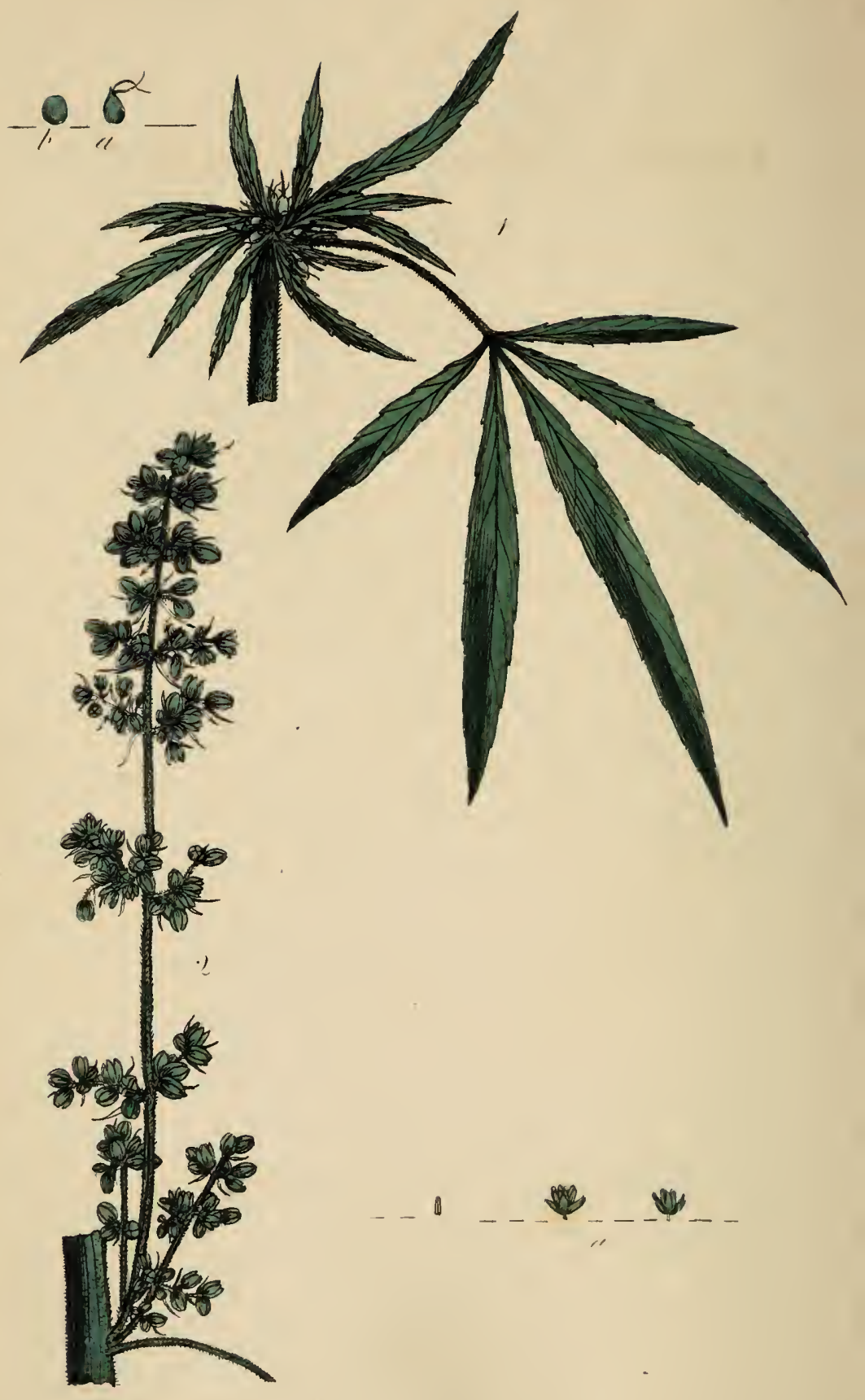




\section{( 63 )}

\section{PLATE XXXII. LETTER XXIX.}

\section{DIOECIA.}

Cannabis sativa. Hemp.

Fig. 1. Female Hemp.

a A single Female flower.

$b$ The seed included within the calyx.

Fig. 2. Male Hemp.

a Male flowers separate. 


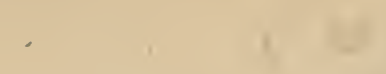

-

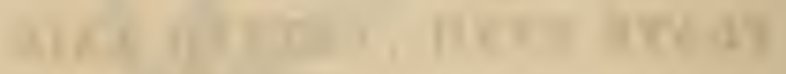

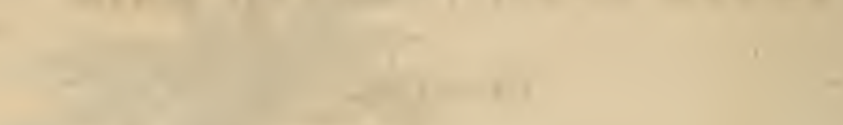

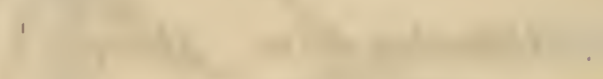

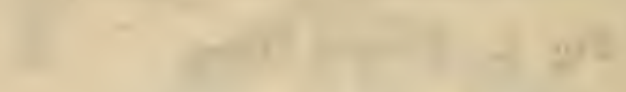

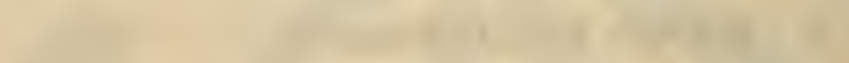
(10.
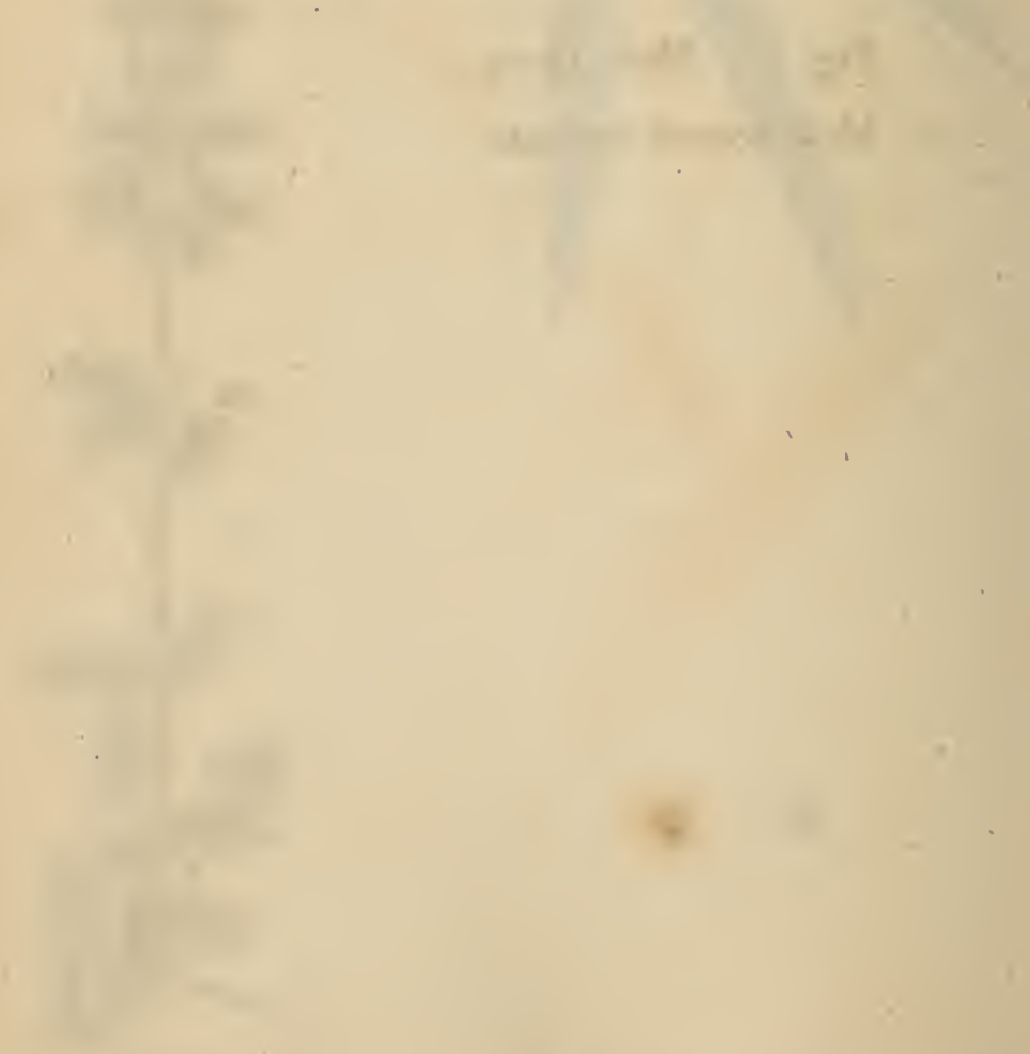


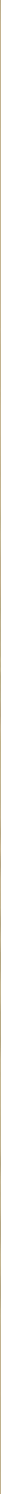




\section{( 65 )}

\section{PLATE XXXIII. LETTER XXX.}

\section{POLYGAMIA MONOECIA.}

\section{Acer Campestre. Common Maple.}

a $a$ The lobed leaves.

$b \quad b$ Bunches of flowers. - $c$ Perfect. d Male, with stamens only.

e A single perfect flower.

$f$ A petal.

$y$ A perfect flower divested of the corolla and calyx.

h A single stamen.

i The pistil, with the two revolute stigmas, and the rudiment of the two capsules, terminating in a wing.

$\dot{k}$ A male, or staminiferous flower, and a single petal of it. 


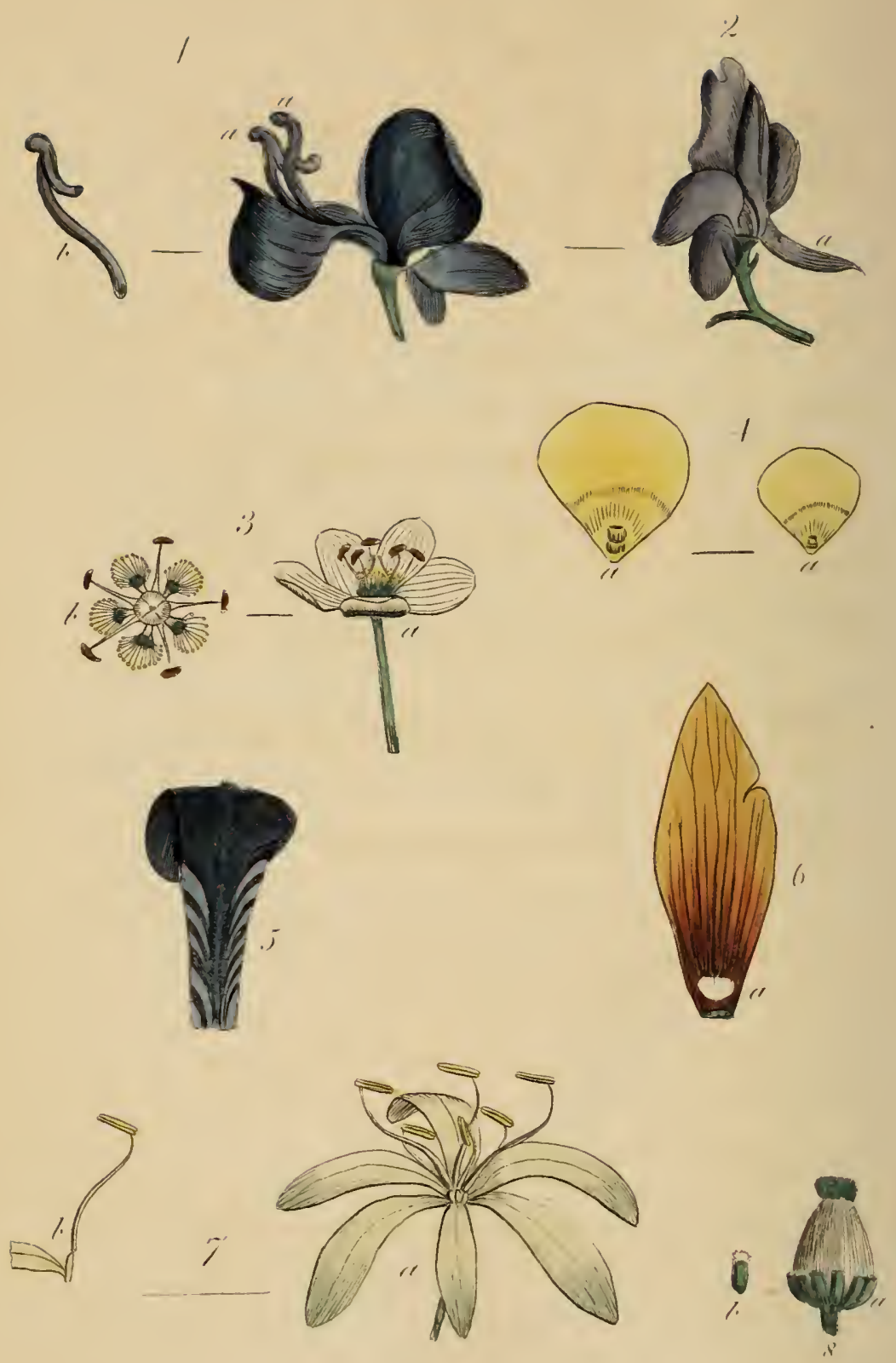

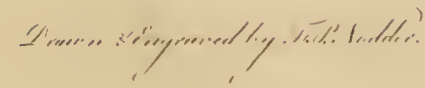

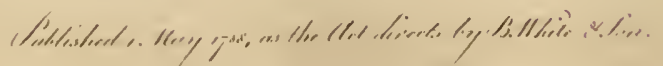




\section{( 67 )}

\section{PLATE XXXIV. LETTER XXXI.}

\section{NECTARIES.}

Fig. 1. Aconitum Napellus. Bhe Monk's Hood.

a $a$ The two recurved pedunculated nectaries.

$b \quad$ A single nectary taken out of the flower.

Fig. 2. Delphinium Ajacis. Garden Larkspur.

a The nectary, continued backward in form of a horn or spur.

Fig. 3. Parnassia palustris.

a A flower, with the nectarious scales at the base of the stamens.

$b$ The five heart-shaped nectaries, terminating in hairs, with a little ball on the top of each, and placed between the stamens.

Fig. 4. A petal of the Ranunculus, showing the honied gland just above the base, on the inside at $a a$.

F 2 . 


\section{( 68 )}

Fig. 5. Iris or Flag. The nectary, in form of a villous line, along the middle of one of the reflex petals.

Fig. 6. Fritillaria Imperialis. Crown Imperial.

a An excavation at the base of the petal, which is the nectary.

Fig. 7. Asphodelus luteus. Yellow Asphodel.

$a$ The flower, showing the six stamens, each sitting on its valve, and the six valves forming an arch over the germ.

$b$ A single filament on its scale, which is inserted into the base of the petal.

Fig. 8. Helleborus foetidus. Stinking BlackHellebore.

"The tubular nectaries placed in a ring at the base of the stamens.

h A siugle nectary. 


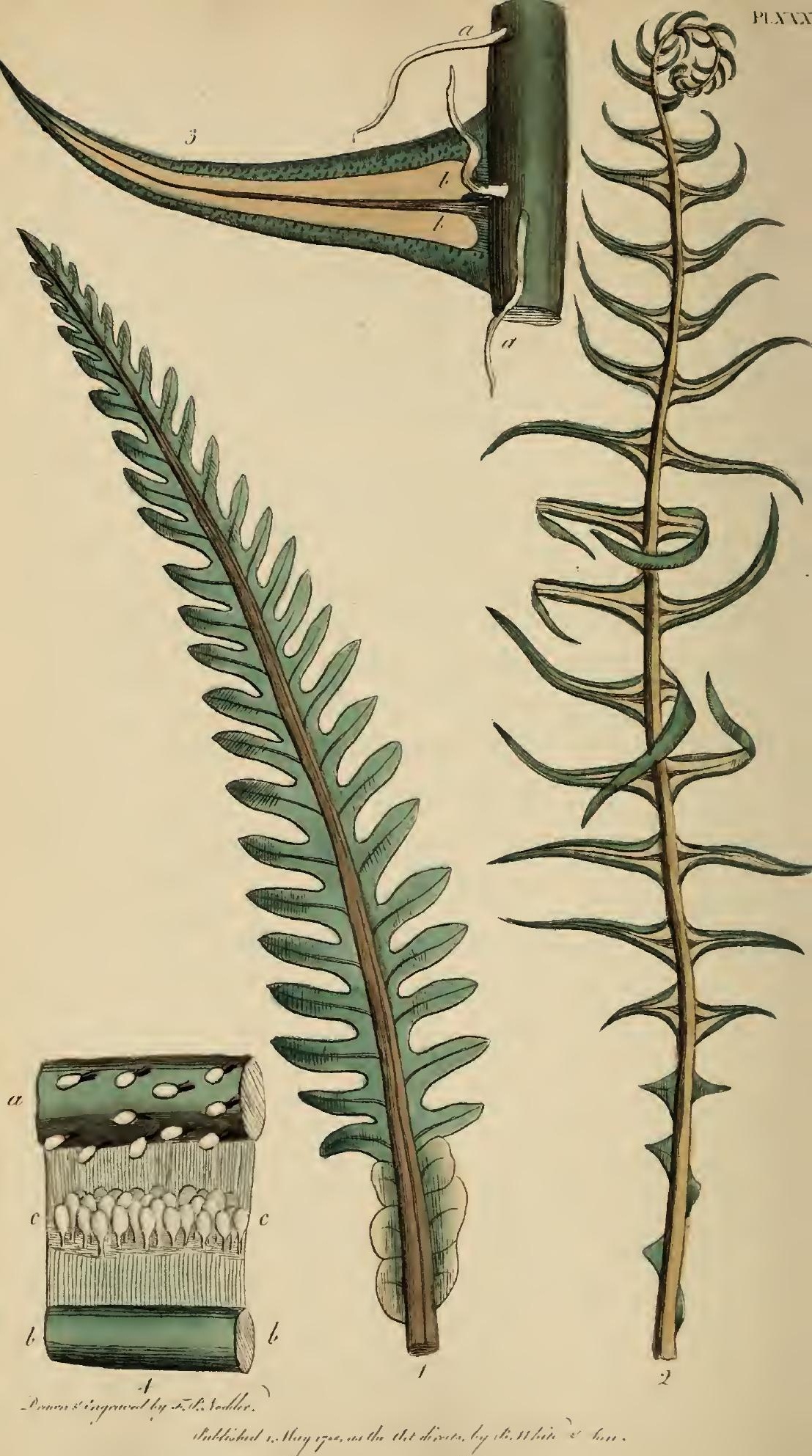




\section{( 69$)$}

\section{PLATE XXXV. I.ET'TER XXXII.}

\section{CRYPTOGAMIA FILICES. Fierns.}

\section{Osmunda Spicant. Rough Spleenwort.}

Fig. 1. The barren frond.

Fig. 2. The fertile frond.

Fig. 3. A single pinna magnified, with the scales at $a a$; and covers of the capsules at $b b$.

Fig. 4. A part of the pinna more magnified, with the anthers of the rib at $a$, and the membrane rolled back at $h b$, to exhibit the rudiments of the seed ressels at $c c$. 


\section{$(70)$}

\section{PLATE XXXVI. LETTER XXXII.}

CRYPTOGAMIA MUSCI. Mosses.

Bryum pyriforme. Pear Bryum.

Fig. 1. The moss of its natural size.

Fig. 2. The anthers yet entire.

Fig. 3. The female flower, while it is yet inclosed within the inmost leaves.

Fig. 4. The same separated, with the appendages, viz. $a$ a the adductors. $b b$ the cylindrical jointed threads. 


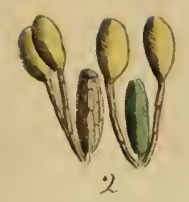

$$
*
$$
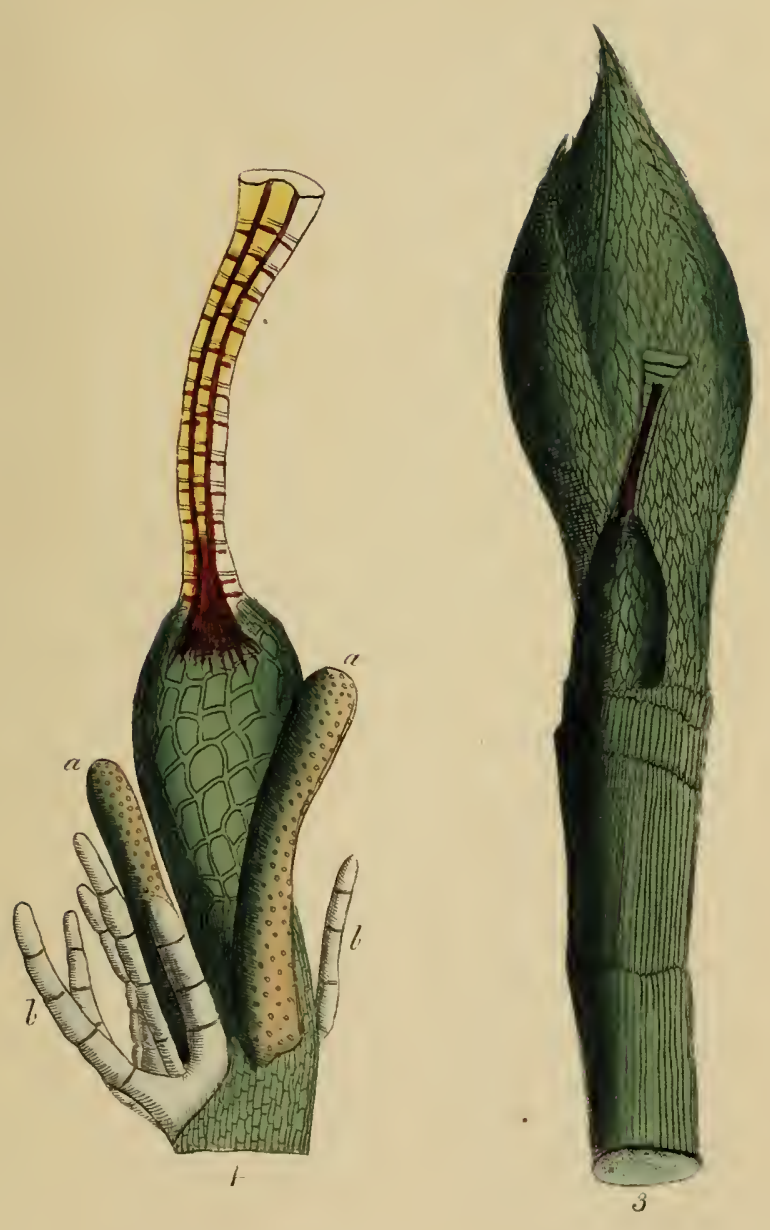

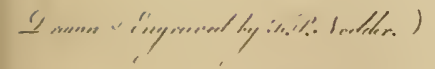





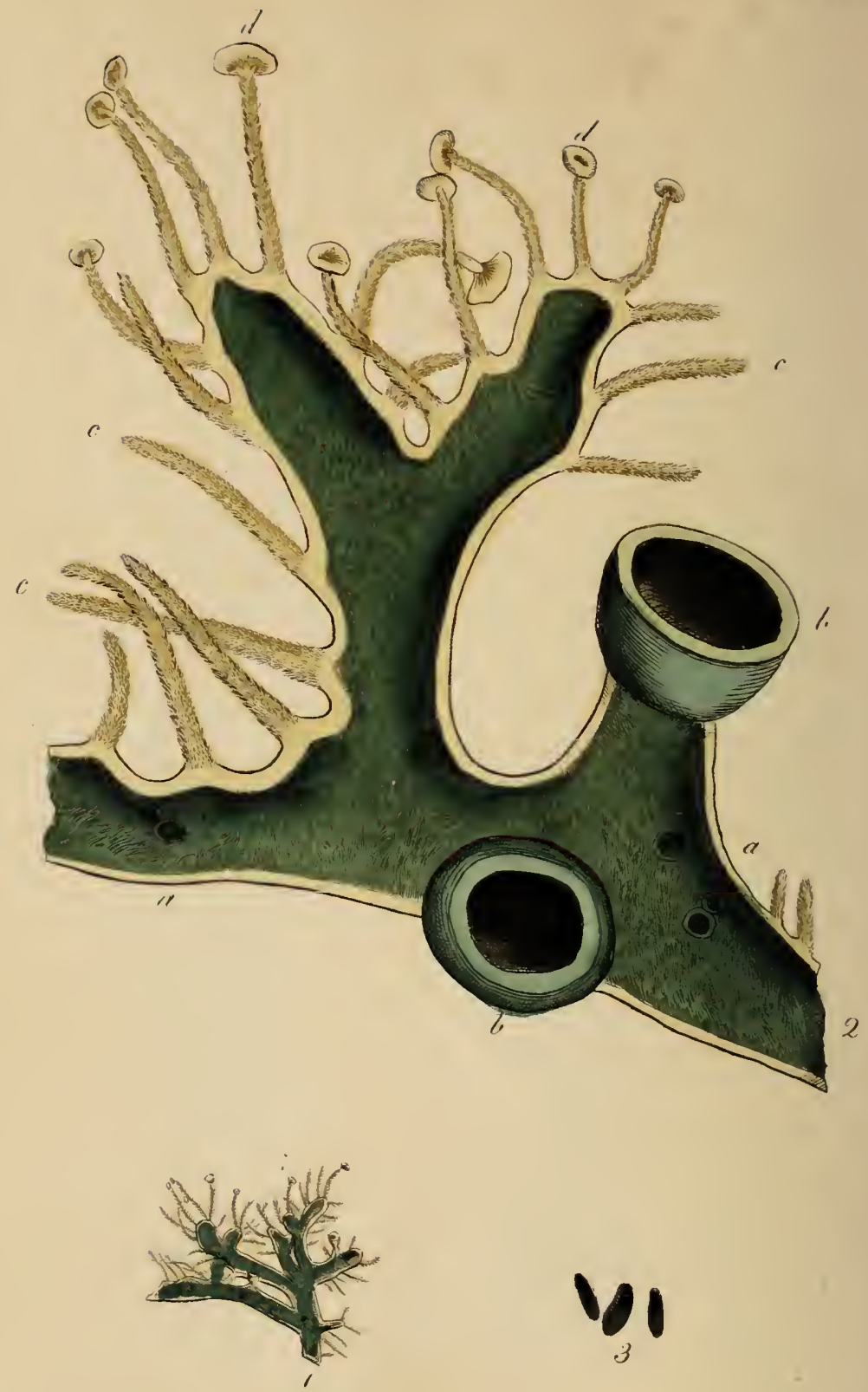

Vol

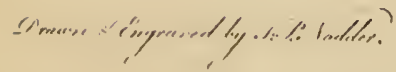




\section{$(71)$}

\section{PLATE XXXVII. LETTER XXXII.}

CRYPTOGAMIA ALGRE.

Lichen ciliaris. Ciliated Liverwort.

Fig. 1. The plant of its natural size.

Fig. 2. The same magnified.

a $a$ The male or barren flowers.

$b b$ The females in a state of ripeness.

$c c$. The rooting hairs.

$d d$ The hairs, or cilix, growing on the extremities.

Fig. 3. The seeds magnified. 


\section{PLATE XXXVIII. LETTER XXXII.}

CRYPTOGAMIA FUNGI. Funguses.

Agaricus Dillen. giss. p. 185.

Fig. 1. Plants of different ages, and of their natural size.

$a$ Is the fungus in its perfect or adult state.

$b$ The same in its middle state.

c Small plants just rising.

Fig. 2. A parcel of knotted threads from the fungus marked $b$, supposed to be the stamens.

Fig. 3. A section of the $\operatorname{cap}(a)$ and lamella (b) of the same small fungus magnified.

Fig. 4. The ripe seeds of this fungus much magnified.

Obs. These four plates are copied from Hedwig's Theoria, as it would have answered little purpose to figure such minute plants of their natural size only.

THE END. 
il. $>111$ III
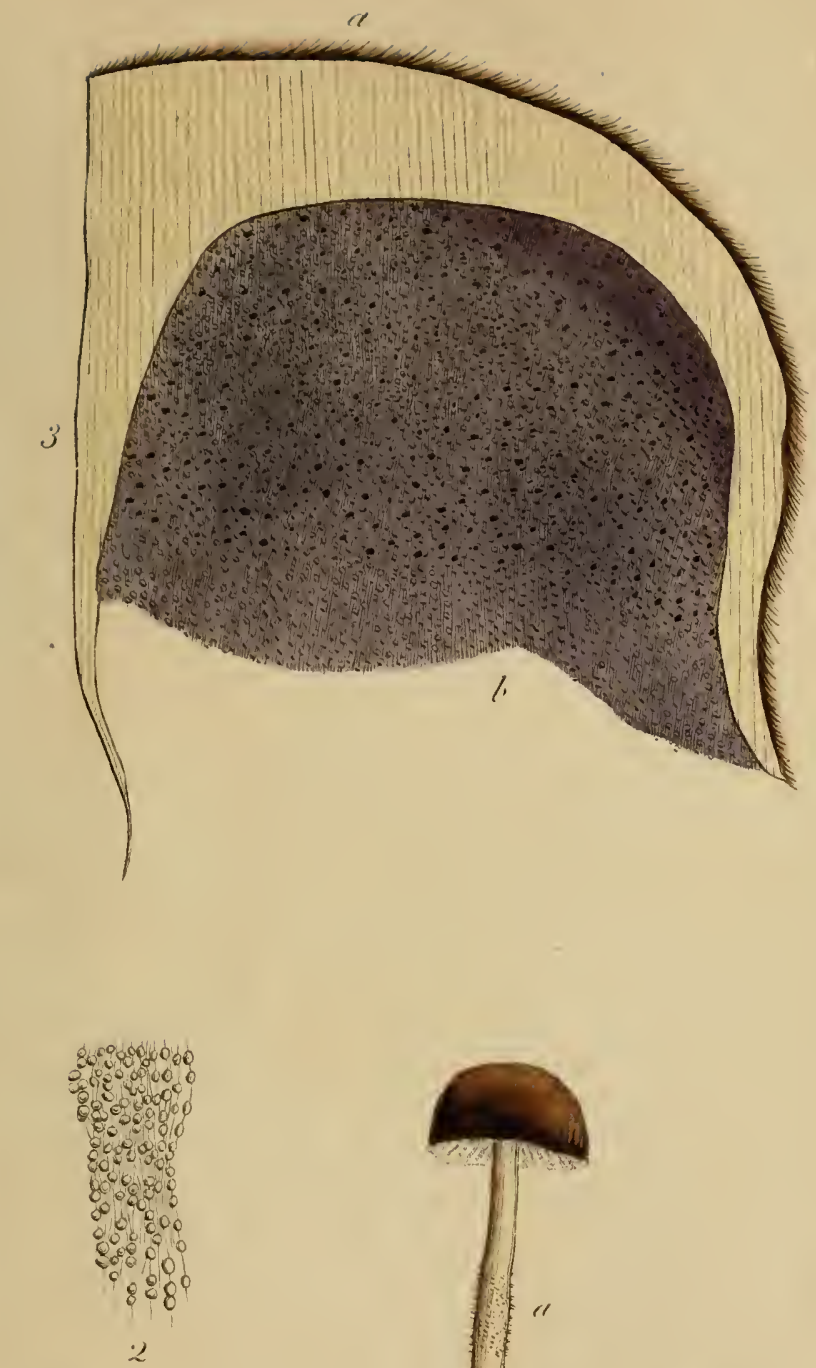

8

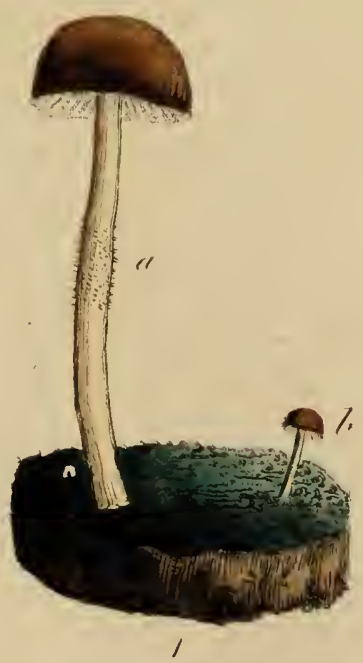

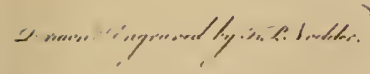

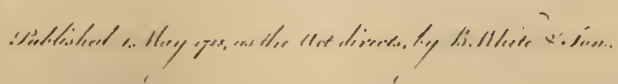


$2.23^{3}-R$ 




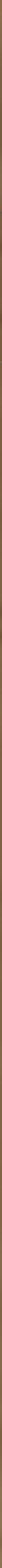
